\title{
1. What is comparative legal history? Legal historiography and the revolt against formalism, 1930-60*
}

\author{
Adolfo Giuliani
}

\section{INTRODUCTION: THE QUESTION}

Thinking of comparative legal history engenders two immediate observations. The first is the exponential growth of this field over the past two or three decades in both research and legal education. ${ }^{1}$ But another and equally remarkable observation is that this rising popularity, curiously, has not dispelled some vagueness about its nature and methods. Whereas legal history (historia juris, histoire du droit, Rechtsgeschichte, historia del derecho, storia del diritto) with its distinguished pedigree that goes back for centuries is a deeply rooted presence in legal scholarship, this more recent field cannot be equally sure of its identity. The question therefore rises naturally: what is comparative legal history?

This chapter offers the answer of a legal historian. It proposes in the first place to view the above question addressed at explaining a change ('How did this field come about?') which involves understanding how the writing of legal history changes in time. The main idea is that the rise of comparative legal history can be viewed as the metamorphosis from one tradition into another, each embedded in a set of assumptions about its subject matter - the law - and the ways to approach it. The aim is therefore to chart a change of mind in the writing of legal history and explain how traditional assumptions that have been guiding it have been questioned and reformulated over another set of insights. No attempt will be made to explain a model of comparative legal history conceived in the abstract or to seek a definition or even less to provide a blueprint for what this discipline ought to be doing.

Some basic ideas are necessary to make this change perceptible. Firstly, it is in the essence of the writing of legal history that there must be a starting point. This is an

* An abridged version of this chapter was presented at the conference 'Legal Theory and Legal History: A Neglected Dialogue?', IVR, Queen Mary University of London, 12 April 2013. Thanks are due in particular to David Ibbetson, Alain Wijffels and Kaius Tuori for helpful suggestions during the draft of this chapter. I am also grateful for profitable discussions with David Nelken, Lauren Benton, Seán Donlan, Luigi Moccia, Emanuele Conte, Gerardo Ramírez Vidal and Giorgio Resta. The usual disclaimer applies.

1 See for example the legal-historical journal Comparative Legal History, launched in 2013 by the European Society for Comparative Legal History constituted in 2009. In legal education, see Kjell Å Modéer and Per Nilsén, How to Teach European Comparative Legal History (Lund 2011) and the project Western Legal Traditions (series Ius Commune Casebooks, Oxford, Hart Publishing), project director Remco Van Rhee. 
image of law with which any style of writing is deeply intertwined. By image of law I mean a set of broad assumptions that the scholars engaged in this field share about their subject matter - the law - and which answers some general questions about what is law, by whom it is created and how. They are the loci communes of the profession. Like a road sign, they offer guidance, provide points of view, order experience, interpret facts and have the authority which is conferred upon them by scholarly consensus. They are the basic points ('loci communes') upon which the discussion in the field is articulated and are perceptible in the books, teaching manuals and academic writings of a scholarly community. Their guiding power lies in the fact that legal historians do not write about an abstract and general idea of law but are concerned with a particular image of law and a specific set of assumptions which further defines it. Legal history cannot be written without such image, as it defines the law which is its object of study. This chapter is particularly concerned with the notion that historical research begins from an idea of its object of investigation, as any historical narration needs a criterion to separate what is relevant from what is not. Without it, the historian simply would not know what to look for.

The image of law I have in mind contributes to explaining how legal historiography changes over time. This image of law is so directly conducive to a particular style of writing that every change in the first is reflected in the second. The earlier set of shared assumptions becomes insufficient to answer new questions, and legal scholars turn to alternative explanations that carry greater heuristic power. They begin from other questions and other ways to search for answers. For the legal historian, that new set of assumptions gives rise to another way of writing legal history. This perspective places this discipline in the broader field of law, deeply intertwined with claims arising from the broader intellectual and institutional context. ${ }^{2}$

The second idea offered by this chapter is that the decades 1930-60 saw a profound turn in European legal science. Some legal scholars refused the hegemonic doctrines of legal science bequeathed from the 19th century and launched an attack on the 'formalism' at the heart of its intellectual framework ( $\$ 1.4)$. And choosing the protagonist of the legal system, to put it in a nutshell, they turned from the legislator to the judge $(\$ 2.1)$. They started from another set of assumptions about 'law'. This change determined the beginning of another phase, which not merely turned upside down the legacy received from the 19th century but also placed legal history under a new light. This essay argues that the rise of comparative legal history must be put in this context. It focuses on the phase in which such change of mind occurred, which today about two generations later becomes visible as an object of historical research, in order to get a precise understanding of what was rejected and what was offered in its place. Those insights, uttered then by some original minds, in the course of time have

2 This approach implies a deliberate attention to the broader field of legal theory, on which see recently Maksymilian Del Mar and Michael Lobban, Law, Theory and History: New Essays on a Neglected Dialogue (2015), see also David Ibbetson, 'What is Legal History a History Of?' in Andrew Lewis and Michael Lobban (eds), Law and History: Current Legal ISSUES (vol 6, Oxford 2003) 33, and William Ewald, 'Legal History and Comparative Law' (1999) 7 Zeitschrift für Europäisches Privatrecht 553 at 556, with reference to the study of the 'styles of legal thought'. 
been generalised into broad assertions which today are taken for granted, and which precisely because of their broadness require to be examined in the context in which they originated.

Before proceeding it seems worth noting that it is usual to say, particularly among comparative law scholars, that comparative legal history is a dialogue - middle-road, integration or intersection - between legal history and comparative law. ${ }^{3}$ But a legal historian would disagree. Historians, suspicious as they are of broad categories, would impatiently ask further questions - which legal history, which comparative law? - as they are inclined to place concepts and ideas back to the historical time to which they belong. In this case, a legal historian would observe that the idea of a dialogue was enlightening at the time it was first expressed - 'history involves comparison', Frederic W Maitland declared in 1911 and 'comparison involves history', Gino Gorla replied in $1964^{4}$ - as it emphasised a comparative element in history and a historical component in comparative law which broadened the scope of the two fields. But since then the two disciplines have lost some of their traits. Today scholars from both fields share a worry: they are adamant that their respective methodological status is in peril. In comparative law, for example, Mathias Reimann has no qualms denouncing the malaise and even the failure that occurred once this field departed from the safe harbour of the classical masters of the 20th century. ${ }^{5}$ Legal historians, on the other hand, share a growing anxiety about the two pillars upon which their discipline rests: law and history. Regarding the first, as we learn from the legal philosopher William Twining, for having an insufficient grammar to explain a vastly changed world; and the second, as the historian Jörn Rüsen denounces, for being weakened by about two decades that decreed history 'to be dead, outdated, overcome and at its end' ${ }^{6}$ It may also be added that legal history and comparative law seem to be engaged by two markedly different scholars: legal historians are practical people who dislike theory, they work with facts; comparatists, on the other hand, are obsessed with methods, and their field seems self-absorbed into a theoretical reflection about its own methodology. ${ }^{7}$ The fact that comparative legal history is welcomed as a fresh start in a time of criticism, as a

3 See for example: Mathias Reimann, 'Rechtsgeschichte und Rechtsvergleichung im Dialog' (1999) 7 Zeitschrift für europäisches Privatrecht 496; Hein Kötz 'Was Erwartet Die Rechtsvergleichung Von Der Rechtsgeschichte?' (1992) 47 Juristenzeitung 20; Mathias Reimann and Alain Levasseur 'Comparative Law and Legal History in the United States' (1998) 46 Am J Comp L Supp 1; K Luig 'Was kann die Rechtsgeschichte der Rechtsvergleichung bieten' (1999) 7 Zeitschrift für europäisches Privatrecht 521; Alex Flessner 'Die Rechtsvergleichung als Kundin der Rechtsgeschichte'(1999) 7 Zeitschrift für Europäisches Privatrecht 8; James Gordley, 'Comparative Law and Legal History' in M Reimann and R Zimmermann (eds), The Oxford Handbook of Comparative Law (Oxford 2006) 753.

4 Frederic Maitland, 'Why the History of English Law is Not Written' in The Collected Papers of Frederic William Maitland, HAL Fisher (ed) (Cambridge 1911) I, 488; Gino Gorla, 'Diritto comparato', in Enciclopedia del Diritto (Milan 1964) XII, 930 n 5.

5 Mathias Reimann 'Progress and Failure of Comparative Law in the Second Half of the 20th Century' (2002) 50 Am J Comp L 671.

6 William Twining, Globalisation and Legal Theory (2000), Jörn Rüsen, Western Historical Thinking: An Intercultural Debate (New York 2014) vii.

7 Dirk Heirbaut 'Comparative Law and Zimmermann's New Ius Commune: A Life Line or a Death Sentence for Legal History? Some Reflections on the Use of Legal History for 
phoenix rising from the ashes of its predecessors, makes the question even more urgent: what is comparative legal history?

The chapter is divided in two main sections. Section 2 describes the 19th-century paradigm of legal historiography analysed in three basic assumptions (purity, textualism, historicism); and section 3 shows how those inherited commitments were overturned giving rise to a new approach based on opposed premises. I need to signal that in what follows I will limit myself to the frame of continental legal history, not only as this is what belongs to my personal expertise, but because continental legal historiography developed within a world of its own, in which legal historians wrote not about law in general but about Roman law. Anglo-American legal history is free from this legacy. ${ }^{8}$

\section{THE 19TH-CENTURY PARADIGM OF LEGAL HISTORY}

\subsection{Friedrich Carl von Savigny}

There is no better place to begin an investigation of continental legal history than with its fountainhead, the German jurist Friedrich Carl von Savigny (1779-1861). Of course to begin our account from the early 19th century may seem an exercise in antiquarianism, but it is nevertheless vital to point out that the writing of legal history has been guided until the mid-20th century by a set of assumptions established by this influential figure. Legal historians lived so long with his name that it is hard today to capture the fervour of his contemporaries for the scholar who set legal academia aflame with his challenging vision of a 'historical legal science' (\$1.12). No one did so much for legal history as Savigny. This discipline owes its foundations, the idea of evolution, the statement of its nature and function to this immensely influential scholar. ${ }^{9}$ He provided a model for the writing of legal history which, because of its originality, its almost universal acceptance and even its 'sacrosanctity', became the paradigm that guided legal historiography in most European countries from the early-19th to the mid-20th century. ${ }^{10}$

Comparative Law and Vice Versa' in (2005) Fundamina: A Journal of Legal History: Essays in Honour of Eric H Pool, 136, at 150-153.

8 But see Mathias Reimann, Historische Schule und Common Law, Die deutsche Rechtswissenschaft des 19. Jahrhunderts im amerikanischen Rechtsdenken (Berlin 1993).

9 Hermann Kantorowicz, 'Savigny and the Historical School of Law', in H Kantorowicz, Rechtshistorische Schriften (Karlsruhe 1970) 419 at 419: 'among the great scholars the name of Friedrich Carl von Savigny is unique in the sense that in his country it has become sacrosanct. By sacrosanct I mean that it is protected by public opinion to the extent that an attack on it no matter how justified is condemned as positively wicked, even as the act of a traitor. ... Such sacrosanctity is an important historical fact'. See also Thomas Duve, 'European Legal History Concepts, Methods, Challenges' in T Duve (ed), Entanglements in Legal History: Conceptual Approaches (Global Perspectives on Legal History) (Max Planck Institute for European Legal History, Open Access Publication, Frankfurt 2014) 42.

10 See on this Joachim Rückert, 'The Unrecognized Legacy: Savigny's Influence on German Jurisprudence after 1900’ (1989) 37 Am J Comp L 121; and generally G Iggers, The 
But Savigny's influence went beyond legal history. He presaged a new beginning to legal science in the name of history, which gave a professional grandeur to legal scholars generally as the keepers of the expertise needed to understand the law. And by claiming that the essence of law was history, he made this discipline important, which gave a leading role to legal historians. Moreover, because Savigny and his school were also the fathers of 19th-century legal science it would be difficult to understand continental legal science in general without being aware of the historiographical conceptions they developed. The rise of those conceptions also rested on the success in the formation of the University of Berlin, founded in 1810 by Wilhelm von Humboldt and immediately thereafter put in Savigny's hands as the first elected Vice-Chancellor. At Berlin he called the best minds of the time, and they formed a formidable professorial community (joined in 1825 by Leopold von Ranke) bound together by the highest methodological standards and by an intellectual project which eventually unified Germany by a common legal culture, shared methods of teaching and above all by that conception of legal science upon which the German code of private law (Bürgerliches Gesetzbuch or BGB) of 1900 was founded. ${ }^{11}$ Because of the cultural leadership exerted by Germany, the whole continent of Europe was bewitched into this project.

\subsection{The 19th-Century Image of Law}

What was this new image of law? Savigny summarised it in two words in the title of his manifesto (Vom Beruf unserer Zeit für Gesetzgebung und Rechtswissenschaft, 1814): legislation and doctrine. They indicated the competing projects to which jurists were called on at that time: the first was the codification of private law undertaken by France culminating in the Code of 1804; and the second was a Roman-law-based science entrusted with the intellectual elaboration of private law (known as Pandectism) that prepared the ground for the BGB enacted in 1900. Such Janus-faced legal science is traditionally ascribed to conflicting legal visions (a historical and non-historical school, according to Savigny), which today however seem less distant and converging on (at least) two main ideas. ${ }^{12}$

The first was the codification of private law. Although promulgated at different times (France 1804, Germany 1900) the codification fulfilled a multi-layered agenda that included a range of objectives, among which were the political project of a unified state sovereignty, the call that resounded through the centuries for a clear and simple law to supersede the imprecision of the ius commune, and the philosophical keenness on a

German Conception of History: The National Tradition of Historical Thought from Herder to the Present (Wesleyan 2012).

11 Mathias Reimann, 'Nineteenth Century German Legal Science' (1989) 31 Boston College Law Review 837, 875-883.

12 This opposition is described in Friedrich Karl von Savigny 'Ueber den Zweck dieser Zeitschrift (On the aim of this journal)' (1815) Zeitschrift Für Geschichtliche Rechtswissenschaft 2. It seems worth noting that Savigny's antagonist, the Heidelberg jurist AFJ Thibaut (17721840), ostracised from legal academia as the mastermind of the unhistorische Rechtsschule and overshadowed by Savigny's rise, is currently viewed as the founder of historicism in music with his Über Reinheit der Tonkunst (1824). 
legal order explained in terms of a law of Reason. These were all embedded in a legal culture obstinately hostile to the ancient régime. ${ }^{13}$

The second idea is that law is state-law and is therefore conclusively expressed in formally enacted texts, to the exclusion of any other source (see below $\S 2.3 .1 .1$ ). This sort of legalism runs deeply in Savigny's legal science. One of the keys to his vision is in fact the stringent fidelity to which the interpreter is bound, and deeply intertwined with it, the primacy of philology. ${ }^{14}$ When we turn for example to some philological masterworks, such as Otto Lenel's Edictum perpetuum (1884) or Otto Gradenwitz' Interpolationen in den Digesten (1887), we realise that those works, written concurrently with the preparation of the $\mathrm{BGB}$, in their obsession with an Urtext purified by alterations ('interpolations') were closely bound up with the idea of law as a text. ${ }^{15}$ Another instance of this legalism is perceptible in the zeal for a logically coherent and complete system of law, pursued by Savigny's followers in Pandectist manuals beginning with the Institutionen des heutigen römischen Rechts published by Savigny's teacher Gustave Hugo in 1789. It is true that the most apparent feature of Savigny's project is a deeply felt sense of history, but it is nevertheless also true that at the same time his success in overshadowing his most direct competitors - natural law scholars and the usus modernus - came from his emphasis on textualism and a systematic idea of law. As Franz Wieacker noted, his textualism challenged natural law scholars by replacing their abstractions with real texts; and eclipsed the usus modernus with a logically sophisticate scholarship that prioritised a systematic outlook. ${ }^{16}$ Those two features - textualism and systematic idea of law - were the two faces of a legalism that pervaded Savigny's project; following which, the two faces of 19th-century legal science - legislation and doctrine - had their sights set on a common ground. They converged not only on the final objective of a codification, but also on the pervasive legalism which led legal scholars to that conclusion. Contrary to Savigny's confident assertions about his movement's uniqueness, the further evolution shows that 19thcentury legal scholars built their intellectual world sharing a broad set of ideas.

A fitting word for Savigny's project is 'formalism', which indicates Immanuel Kant's idea of a dualism of matter and form, on which Savigny fixed his attention and which inspired his project of a legal science purified from external contaminations. ${ }^{17}$ One of the most characteristic features of this pervasive idea of legal science, was to view law

13 L Lombardi, Saggio sul diritto giurisprudenziale (Milan 1967) 207-208 and Raoul Van Caenegem, European Law in the Past and the Future (Cambridge 2001) 69-70.

${ }^{14}$ For a general orientation see D Kelley, 'Philology and History' in J Rabasa, M Sato, E Tortarolo and D Woolf (eds), The Oxford History of Historical Writing: Vol. 3: 1400-1800 (Oxford 2015) 233.

15 Franz Wieacker, A History of Private Law in Europe (Tony Weir trans, Oxford 1995) 333; on the rise of a philologically-based image of classical Roman law see Kaius Tuori, Ancient Roman Lawyers and Modern Legal Ideals: Studies on the Impact of Contemporary Concerns in the Interpretation of Ancient Roman Legal History (Frankfurt 2007) 168.

16 Wieacker, A History of Private Law in Europe, supra note 15, at 292-299.

17 Ibid at 295 and 328. According to Wieacker (p. 295), 'one has to agree with Kantorowicz and Wilhelm that his [Savigny's] renewal of legal science consisted essentially of the re-establishment of formalism'. 
as a depurated knowledge. But this achievement came at a high price, as it implied a boundary that separated the 'purely legal' from all other forms of non-legal normativity.

\subsection{Legal History Before Savigny}

When we turn to legal historiography we realise that the project pursued by 19thcentury jurists not only changed the law but also introduced a fresh approach to writing its history. The new start was heralded by Savigny's teacher, Gustav Hugo. His legal history manual (Lehrbuch der Geschichte des Römischen Rechts, 1790) announced a writing style based on an original view of history and law. ${ }^{18}$ It swept away a time-honoured tradition in which legal history (not unlike any other legal topic) had its own place in the Corpus Iuris, in Pomponius' text On the origin of law (De origine juris, D. 1.2.2). ${ }^{19}$ This text was a perfect model for the writing of legal history. It offered an account of three phases of legal evolution, beginning with the early customary law (mores) of archaic Rome through all forms of legislation (leges regiae, XII Tables), the jurisprudential creations (interpretatio, actiones, senatusconsulta) up to the imperial constitutions, followed by the evolution of political institutions. Finally, it charted the uninterrupted succession of jurists up to Pomponius' own time. The first legal historiographers added commentaries, and then autonomous treatises to this text. The rise of historical sense in the 16th century highlighted its extraordinary importance, confirmed for example by Guillaume Budé, Ulrich Zasius and Aymair du Rivail. All later teaching manuals followed in their wake and shaped their exposition upon this archetype. This tradition faded between the 18th and 19th centuries. Legal historians increasingly turned away from the model offered by Pomponius and experienced a growing distance from earlier ways of writing legal history. Legal historiography mirrored the rise of a new paradigm in the understanding of law.

We now turn to three basic assumptions that guided this new style of legal historiography: the exclusive concern with black-letter law (textualism); the separation of law from its context (purity), and the idea of cumulative development (historicism).

\subsubsection{Textualism: the exclusive concern with black-letter law}

2.3.1.1 Textual authority I turn first to consider textualism, a term which in this chapter is meant to indicate the assumption that legal authority is exclusively expressed in formally enacted texts. This idea brings us directly to the pathos of 19th-century codifications and to the century's characteristic commitment to see law primarily as a written text. As the great commentator of the Code Civil Charles Demolombe (1804-1887) confidently asserted: '[m]a devise, ma profession de foi: les textes avant

18 Gustave Hugo, Lehrbuch der Geschichte des Römischen Rechts (1st edn, Berlin 1790); see $\S$ XXIV stressing the distance from earlier works because of new sources. See parallel developments in the writing of the history of philosophy in Richard Tuck, "The "Modern" Theory of Natural Law' in A Pagden (ed), The language of political theory in early-modern Europe (Cambridge 1987) 99.

19 This paragraph is based primarily on G Crifò, 'Pomponius, liber singularis enchiridii D. 1.2.2 e la storia del diritto' in G Crifò, Materiali di storiografia romanistica (Turin 1998) 51, at 56-64. 
tout!' 20 One of the implications is that beyond black-letter law there is no law and other modes of normativity which are not formalised in writing, transcend the world of law. ${ }^{21}$ If so, the expression 'unwritten law' amounts to nothing better than a contradiction in terms; and natural law, which is unwritten, in this environment develops as a set of first principles which belong to philosophy, not to law. ${ }^{22}$ But for the purposes of our argument, the implication of momentous importance is that textualism is one of the leading principles in a constitutional architecture built upon a clean-cut distinction between law-making and its application. Beginning from the idea that a clear and unambiguous text makes interpretation unnecessary (in claris non fit interpretatio), the judges are in the position of applying rules to the disputed facts mechanically, connecting them by a simple syllogism. It follows an idea of interpretation which another commentator of the Code Civil, François Laurent (1810-87), concisely expressed in the following terms: 'Les codes ne laissent rien à l'arbitraire de l'interprète. Celui ci n'a plus pour mission de faire le droit, le droit est fait' ${ }^{23}$

Textualism is one of the keys to understanding the civilian tradition. At its heart is the commitment to the idea that legal authority is text-based, which most characteristically shaped the thinking of the scholars engaged with this tradition. As it is well-known, this tradition begins from Justinian's Corpus Juris Civilis, an immense compilation of juristic texts, in which the interpreters found all the concepts, doctrines and ideas they needed; they had no extra-textual curiosity, in line with the admonishment uttered by the glossator Francesco Accursio (c. 1181-c. 1259): 'everything is to be found in the Corpus Juris'. ${ }^{24}$ This text was a self-sufficient source of legal knowledge. It is more difficult to explain the basis of its authority, usually confirmed on the strength of a number of elements, among which are its imperial origin, its antiquity, its perfection, even a certain aura of sacrosanctity, ${ }^{25}$ but there are two further elements that need to be highlighted. The first, which is one of the deepest beliefs with which this tradition is intertwined, is that at the heart of a norm is reason and this cannot be separated from its written form: there is no reasoning without a written text (ratio scripta). ${ }^{26}$ Such intrinsic coherence makes the text a self-standing creature which can ideally be applied without interpretation. Texts impermeable to interpretation have

20 Jean Charles Florent Demolombe, Cours de Code Napoléon (Paris 1845) vol 1, préface, VIII ('My motto, my profession of faith: the texts before anything else!').

21 The expression 'black-letter law' refers to the Gothic type at the beginning of formal statements of law.

22 On the shift of natural law from a set of rules into a legal philosophy, see Merio Scattola, 'Models in the History of Natural Law' (2001) 28 Ius commune. Zeitschrift für Europäische Rechtsgeschichte 91.

23 See on this generally Caenegem, European Law in the Past and the Future, supra note 13, at 62 ('Codes leave no room to the interpreter's discretion, for his mission no longer is to make the law, as the law is already made').

24 Accurius, Gl. notitia ad D. 1.1.10: 'omnia in corpore iuris inveniuntur', on which see E. Cortese, Il diritto nella storia medievale (Rome 1995), II, 185.

25 See on this Nils Jansen, The Making of Legal Authority (Oxford 2010) 28-45.

26 See, for example, the incipit of Gratian's decretum (dist. I, 1): 'Ius naturale est quod in lege et evangelio continetur', discussed in P Prodi, Una storia della giustizia (Bologna 2000) 112-122; E Cortese, La norma giuridica (Milan 1962), I, 37-95, 286-289; J Vanderlinden, Le concept de code en Europe occidentale (Bruxelles 1967) 161-215. 
an immense authority, which arises from the fact that they rule to the exclusion of any other source. Given this context, we can hear a positivist ring in the recurrently heard exhortation to go back to the sources to recover an Urtext cleansed from the interpretations that tarnish its perfection - the Accursian filth, according to François Rabelais. ${ }^{27}$

The second element arises from the fact that textualism implies fidelity to the text. There is no other word but fidelity to describe the meta-rational authority exerted by the text, which demands reverence and profound attachment because of its uniqueness at the exclusion of any other. The interpreter believes in the text's authority. This is in fact the premise to study it dogmatically: to know it means to accept it. ${ }^{28}$ Such fidelity - cognate with the love of learning ( $\varphi$ i $\left.\lambda \mathrm{o} \lambda \mathrm{o} \boldsymbol{\gamma}^{\prime} \alpha\right)$ that moves the philologist - incorporates a deep, meta-rational and obsessive commitment to the text that is the object of such feeling. Such text is sacralisé. ${ }^{29}$

2.3.1.2 Textualism and legal historiography It is true that any age had its defenders of textualism, as the project of a codification (in its many forms) has been pursued for centuries, but it is nevertheless true that nobody glorified it to such an extent as the artificers of the French codification between the 18th and 19th centuries. They launched the strongest attack on interpretation. Because in the ancien régime the Roman text was obscured by layers of interpretations (glossae, commentaries and juristic opinions), often conflicting and thus a source of uncertainty, they were to be eliminated. If so, textualism had a role in the power game fought between legislators and judges. Legislation requires faithful interpreters.

One of the major outcomes of the French Code Civil (1804) was to introduce new principles of interpretation. ${ }^{30}$ The fundamental premise was that all the law was included in the code and this was the specimen of a clear law, and so simple and complete that the role of judges changed dramatically. To apply the law did not imply any creative function, so that they were just passive interpreters. 'It is the law that speaks, the judges are merely its instrument', John Dawson wrote. ${ }^{31}$ Judges must look for the legislative intention and proceeded by syllogisms which connected specific facts to general and abstract norms, so confirming that codified law had solutions for all

27 François Rabelais describing Pantagruel's university days at Bourges: 'Car (disoit-il) au monde n'y a livres tant beaulx, tant aornés, tant élegans comme sont les textes des Pandectes: mais la brodure d'iceulx, c'est assavoir la glose de Accurse, est tant salle, tant infâme et punaise, que ce n'est que ordure et villenie', cited in François Rabelais, Selected Readings, WF Smith (ed) (Cambridge 1920) 68.

28 Tomasz Giaro, 'Diritto Romano Attuale. Mappe Mentali E Strumenti Concettuali' in PG Monateri (ed), Le Radici Comuni del Diritto Europeo (Rome 2005) 77, 79.

29 JL Halpérin, Histoire du droit privé français depuis 1804 (Paris 1996) 45.

30 On which see JL Halpérin, L'impossible code civil (Paris 1992) and E Gaudemet, L'interprétation du code civil (Paris 2002), stressing a line of continuity uninterrupted by codifications in R Zimmermann, Roman Law, Contemporary Law, European Law (Oxford 2001) $52,98$.

31 John Dawson, The Oracles of the Law (Cooley lectures of 1959, Ann Arbor 1968) 411. 
cases, which judges applied mechanically. They were just 'la bouche de la loi' ('the mouthpiece of the law'). ${ }^{32}$

What has not been sufficiently considered is that textualism found an ally in legal history. One of its main contributions was to offer an original narrative whose highlight was the opposition between two schools of jurists - bartolism and humanism - that respectively collected the interpreters and the guardians of the text. It is important to situate this new historiographical style within the broader context of university teaching. A few days away from the code's enactment (21 March 1804), a major reform reshaped legal education. Besides the institution of 12 central schools of law (Écoles centrales) in the major cities of France, at the heart of the project was an educative project addressed to a new public of civil servants whose main interest was the civil code, which was accordingly taught by a mechanical study based on textual exegesis, article by article. At first, legal history had no place in such a technically-oriented curriculum, but soon some legal scholars demanded a broader approach which led to an increased concern for historical and philosophical studies, evidenced by the foundation of an influential historical journal (La Thémis), a wave of historical-philosophical writings and eventually a reform (24 March 1819) which introduced a chair of legal history in Paris, to which was appointed the legal historian Jacques Berriat-Saint-Prix (1769-1845). ${ }^{33}$ His teaching manual, published under the decisive title of Histoire $d u$ droit romain, suivie de l'histoire de Cujas (1821), not only registered the recent changes in the law, it introduced a new way to write its history.

\subsubsection{A new word: bartolisme Berriat-Saint-Prix's teaching manual introduced a} radical break with the writing practices of earlier historians. When we compare it with pre-19th century manuals (see below) we realise that this book re-wrote the picture of legal evolution, how the law was created and the choice of the actors who determined change in the law. Its peculiarity was a simple narrative describing the struggle between two conflicting approaches to the Roman text: Bartolistes and Cujaciens. ${ }^{34}$ On one hand was Jacques Cujas (this work is still cited as one of the main standard reference works on this author), who, armed with historico-philological methods, scanned the Corpus Juris Civilis looking for errors. He wanted to restore the Roman text to its pure and even typographical exactness, and his work, by defeating bartolisme, marked the beginning of modernity. On the other hand was the evil - bartolisme - the word that summarised the dislike for the ancien régime, and particularly for the interpretive

32 Montesquieu, Esprit des lois, p. I, 1. XI, cap. 6: 'Mais les juges de la nation ne sont ... que la bouche qui prononce les paroles de la loi, des êtres inanimés, qui ne peuvent moderer ni la force, ni la rigueur', cited in Dawson, The Oracles, supra note 31, 407.

33 Jacques Berriat-Saint-Prix, Discours sur l'enseignement du droit en France avant et depuis la création des écoles actuelles (Paris 1838) 37-38. On this evolution see JL Halpérin, 'Un gouvernement de professeurs, réalité ou illusion?' in JL Halpérin (ed) Paris, capitale juridique (1804-1950) (Paris, 2011) 45; P Jestaz and C Jamin, La doctrine (Paris, 2004) 69; J Bonnecase, Qu'est-ce qu'une faculté de droit? (Paris 1929) 81; and J Imbert, L'enseignement du droit dans les Écoles centrales sous la Révolution, in Annales d'histoire des Facultés de droit, III (1986) 37.

34 Jacques Berriat-Saint-Prix, Histoire du droit romain, suivie de l'histoire de Cujas (Paris 1821), 300-313, 313-316. 
layers added by the ius commune jurist, who in this account was the negative force that hampered the rise of modernity. The book's title is precise: Histoire du droit romain, suivie de l'histoire de Cujas. This argument cannot be fully appreciated without realising that it vindicated an uncompromising fidelity to the text. Berriat begins from a specific image of law, whose authority is text-based. His bleak account of bartolisme describes one form of application of law wholly divergent from 19th-century France, whose judges applied the law with a mechanical automatism that ruled out judicial discretion. While in the ancient régime the application of law required a juristinterpreter who co-operated in the law-making process, Cujas and his followers, with their uncompromising philological coherence, were the guardians of textual purity.

Berriat's argument was original. It is true that the hostility to bartolists had been a running theme for centuries. They were blamed, for example, for being unaware of the appropriate language for legal science, and thus condemned for the barbarous Latin used by Bartolus and his followers; they were victims of the broad attack launched against medieval scholasticism, a source of niceties that muddled legal thinking and of the probabilism that made legal practice uncertain; they also paid the price for their ignorance of history and philology and thus for their carelessness about the Roman Urtext. Such animosity punctuates all sorts of legal texts, often with a stinging polemical edge; but such hostility had been absent from legal history manuals published before the late 18th century. Those works, shaped upon the archetype of Pomponius' fragment $O n$ the origin of law seen above $(\$ 2.3)$, routinely included a section on the different schools of interpreters that had appeared before Justinian, identified by their competing approaches to the Roman text, then followed by the schools of interpretation constituted after the 11 th century. ${ }^{35}$ But they were not viewed in a judgemental light: what unified pre-19th century legal history was the absence of either praise or criticism.

Let us turn to some major textbooks published in the 18th century. We find that Gian Vincenzo Gravina's De ortu et progressu iuris civilis (1701) registers the different phases of ancient jurisprudence and the existence of four schools after the renewal of jurisprudence. Claude-Joseph Ferrière's Histoire du droit Romain (1783) is silent about a rivalry between schools: the character of the mos italicus is given by a teaching methodology summarised by the well-known mnemonic distich and by the succession of ratio dubitandi and ratio decidendi. ${ }^{36}$ In his Histoire de la jurisprudence romaine (1750) Antoine Terrasson sounds even philo-bartolian. Not only negative opinions on Bartolus are absent but he registers the grand epithets (Speculum, Lucerna Juris, Magister, Pater, Lumen) and the authority of the opinio Bartoli in Spain, adding: 'Il s'en faut bien que les écrits de Bartole ayent une si grande autorité en France. Ce proverbe François, résolu comme Bartole, vient de ce que ce Jurisconsulte étoit ferme

35 For example, the late-16th century jurist Giulio Pace spoke of five different schools beginning from Glossators up to his time, Giulio Pace, 'De iuris civilis difficultate ac docendi methodo' in Nikolaus Reusner, Cynosura iuris, II, Spira, 1588, 81-105.

36 Claude Joseph Ferrière, Histoire du droit Romain (Paris 1783) 450-452. On the mnemonic distich 'praemitto, scindo, summo, casumque figuro/perlego, do causas, connoto et obiicio' see Ian Maclean, Meaning and Interpretation in the Renaissance: The Case of Law (Cambridge 1992) 102. 
dans ses sentiments, \& les débitoit avec beaucoup d'assurance'. ${ }^{37}$ Terrasson registers the consideration received by Bartolus' works in Italy and Germany, remarking that 'ils l'ont été en France pendant très long temps ... j'ignore la raison pour laquelle ils y sont a présent plus négligés qu'ils doivent être'. ${ }^{38}$ Without raising an eyebrow he tells us that in his Sylva Nuptialis (1518) Giovanni Nevizzano argued for marriage in the first half of his book and then argued to the contrary in the second half. In his often-cited Historia juris Romani (1733) Johannes Heineccius registers the ignorance of philosophy and history of Bartolus and his school, but is also careful to add that their methods dominated German legal education in the 15th and 16th centuries. He underlines the splendour introduced by Andrea Alciato and the jureconsulti humaniores but concludes with a devastating attack on the union of elegantiores litterae and law. This textbook's ending note is that humanists, by relentlessly pouring derision upon Justinian and hunting for antinomies and Tribonianisms, just prevented the construction of a solid jurisprudence. In fact, they were 'not jurists, but censors created without people's suffrage' (non jureconsulti, sed censores sine populi suffragio creati). Like the Critics described in Cebes Thebanus' Tabula (a moralistic work well-known until the 18th century) they fell prey to the illusions of False Erudition. ${ }^{39}$

Berriat-Saint-Prix edged away from those earlier works and pitted his work against bartolisme. He condemned it for what it effectively was: a technique for the production of new norms. The jurist could wrap the Roman text in the Scholastic dialectical apparatus - the succession of quaeritur, videtur quod, in contrarium facit, ad solutionem ${ }^{40}$ - and thus produce new law. But this operation downgraded the Roman text to a mere starting point to produce further norms. His greatest chagrin concerned the idea of interpretation it implied. It contradicted his view of legal authority, which did not stem directly from the text but from the doctors, whose collective creations had authority in a system in which their learned opinions were accepted by the courts. In Bartolus' world, the interpreters were also the creators of law.

Rummaging through the immense ius commune literature Berriat-Saint-Prix found a snippet from Raffaele Fulgosio (1367-1427) that asserted the primacy of the Gloss over the Roman text:

37 Antoine Terrasson, Histoire de la jurisprudence romaine (Lyon 1750) 409-410 ('It must indeed be the case that Bartolus' writings should have such authority in France. The French phrase "resolved like Bartolus" comes from the fact that this jurist had firm opinions and expressed them with much assurance').

38 Claude Joseph Ferrière, Histoire du droit Romain (Paris 1783) 420 ('They were much considered in France for a long time ... I do not know why they are presently more neglected than they should be').

39 Johann Gottlieb Heineccius, Historia juris Romani (Halle 1733) lib. I, §§ 350, 351-353.

40 This list is borrowed from Theodor Viehweg, Topik und Jurisprudenz (Munich 1953, Ital. translation Milan 1962) 78-83, with reference to Bartolus' Consilia and Commentaria in primam Digesti novi partem. 
I would rather be supported by the Gloss than by the text. If I refer to the text, then the lawyers of the adverse party and even the judges say, do you think that the Gloss has not examined the text as well as you have, or understood as well as you? ${ }^{41}$

Berriat-Saint-Prix cried scandal. He saw a world turned upside down in which one party argued from the Roman text and was contradicted by the other who argued from the Gloss; indeed, if the judge passed judgment on the basis of the Roman text, he would have been liable for overlooking learned opinions. ${ }^{42}$ Only interpretation counted in that world.

Berriat-Saint-Prix's textbook shows how legal historiography is strictly bound to an image of law, which describes what law is, by whom it is created and how it is applied. Thus choosing the actors who have creative powers in the legal system - judges, legislators or professors - is vital. When we realise that 19th-century France chose the legislator, the attack launched on bartolisme makes sense. Bartolisme, understood as the dialectical apparatus of the ius commune jurist, brings to our attention one particular form of the application of law, functional to an institutional context wholly divergent from 19th-century France and in which the judge was not the "la bouche de la loi'. Textualism, namely the assumption that law is confined to a formal text, ruled out interpretation from the outset. Berriat intended to draw a boundary that separated his time from the ancient régime and his arguments successfully expelled the juristinterpreter with his creative techniques. He contributed to the passing of that earlier epoch into oblivion: he swept away probabilism and its Aristotelian sources as old superstitions. Bartolism found a place among the debris of an age of darkness and barbarism. At that time, Berriat told his readers, courts even tried rats. Only recently we have been willing to reassess that epoch in a new spirit of enquiry, and even reconsider what judges thought at that time and ask, as William Ewald did, 'What was it like to try a rat?'43

Today's legal historians have inherited from Berriat the word bartolisme and, accordingly, the dramatic separation between bartolisme and Humanismus (another 19th-century neologism). ${ }^{44}$ Those terms, like other 'isms', belong to an ideologically

41 Raffaele Fulgosio, Commentary ad legem si in solutum, Cod. de obligationibus et actionibus (C 4.10.1.6), In primam Codicis partem Commentaria (Lyon 1547), fol 183vb: 'Si allego textum, dicunt advocati adversariae partis et etiam iudex: credis quod glossa non ita viderit textum sicut tu et non ita bene intellexerit sicut tu?' cited in Berriat-Saint-Prix, Histoire du droit Romain, suivie de l'histoire de Cujas (Paris 1821) 297-298. Fulgosius' text is also cited in Heineccius, Historia iuris romani, supra note 39, § 417.

42 This rule is elucidated in Dominicus Tuscus, Practicae conclusiones iuris (9 vols, Lyon 1661) conclusio 150 , with further citations.

43 William Ewald, 'Comparative Jurisprudence (I): What Was It like to Try a Rat?' (1995) 143 University of Pennsylvania Law Review 1889, though unaware of Berriat's study: Berriat-Saint-Prix, Rapport et recherches sur les jugements relatifs aux animaux, in Mémoires de la Société des Antiquaires de France (Paris 1829), tome VIII, 403.

44 On bartolisme see Berriat, Histoire du droit romain, supra note 34, at 582 and A Giuliani, 'Una nota sul bartolismo' in Atti del Convegno su Bartolo da Sassoferrato (2014) 585. The word 'Humanismus' was seemingly first mentioned in FJ Niethammer, Der Streit des Philanthropinismus und des Humanismus in der Theorie des Erziehungs-Unterrichts unsrer Zeit (Jena, 1808), and then popularised by Jacob Burckhardt's Civilisation of Renaissance in Italy 
charged narrative, whose actors are intellectual forces that act in opposition - the good and the evil, winners and losers, progress and decay - that explain in a short and simple way the world as it is. ${ }^{45}$ Today, as the grip exerted by the 19th-century paradigm is loosening, that divide is fading away, too. Berriat's first disparaging example of bartolisme - the jurist Étienne Forcadel - is today re-classified as humanist, ${ }^{46}$ and legal historians are increasingly hesitant to assign their familiar labels. Even the most well-known names - e.g. Alberico Gentili, Didaco Covarrubias, Jacopo Menochio - are source of puzzlement: are they humanists or bartolists? ${ }^{47}$ Unsure of the difference, legal historians increasingly find themselves wrestling with the big words inherited from the 19 th century.

\subsubsection{Purity: the distinction between internal and external history}

2.3.2.1 Separating law from its context I now turn to another assumption that guided 19th-century legal historiography: 'purity'. In this chapter this word is meant to indicate the idea that law can be conceived in isolation from the context in which it operates and can thus be conceptualised as a pure entity. The main implication is that it must be defended against all possible contaminations by keeping away all forms of non-legal normativity, or in short, by separating law from facts. This idea is deeply intertwined with an intellectual root of the continental legal tradition - whose genesis may be variously traced back to Francisco Suarez, Christian Wolff and Gottfried W Leibniz ${ }^{48}$ - and finds its most revealing illustration in Hugo Grotius' statement that law can be separated from facts, as mathematicians do with their geometrical figures. ${ }^{49}$

(1860) to indicate the turn away from medieval scholasticism and a forward-looking rise of individualism, on which see Hilde de Ridder-Symoens (ed), A History of the University in Europe, general editor W. Ruegg: Volume 1: Universities in the Middle Ages (Cambridge 1992) 443.

45 Harro Hopfl, 'Isms' (1983) 13 British Journal of Political Science 10.

46 Wim Decock, Law on Love's Stage: Étienne Forcadel's (c.1519-1578) Cupido Jurisperitus in S Kroll, V Draganova, H Landerer and U Meyer (eds), Die Inszenierung des Rechts/Law on Stage (München 2011) 17-36 at 17. On Berriat's 'bartolisme' in reference to Étienne Forcadel, see supra note 44.

47 On Alberico Gentili see A Wijffels 'Antiqui et Recentiores: Alberico Gentili - Beyond Mos Italicus and Legal Humanism' in PJ du Plessis and JW Cairns (eds), Reassessing Legal Humanism and its Claims: Petere Fontes? (Edinburgh 2015) 11. On Covarrubia see A Giuliani, 'D Covarrubias y Leyva, Variarum Resolutionum ex jure pontificio regio et caesareo, 1552' in A Wijffels, S Dauchy et al. (eds), The Formation and Transmission of Western Legal Culture. 150 Books that Made the Law in the Age of Printing (Berlin 2016) 88-91, and A Wijffels, Introduction historique au droit (Paris 2010) 199-201.

48 James Gordley, The Jurists: A Critical History (Oxford 2013) 165-194. I trace back this statement to practitioners' writings published in the late 16th century, in A Giuliani, 'Civilian Treatises on Presumptions, 1580-1620' in R Helmholz, The Law of Presumptions: Essays in Comparative Legal History (Comparative Studies in Continental \& Anglo-American Legal History, Berlin, 2009) 21-71.

49 Hugo Grotius, De iure belli ac pacis [1625] Prolegomena 58, p. XXXVII: 'Just as mathematicians treat their figures as abstracted from bodies, so in treating law I have withdrawn my mind from every particular fact' (Vere enim profiteor, sicut mathematici figuras a corporibus semotas considerant, ita me in iure tractando ab omni singulari facto abduxisse animum). See 
Nineteenth-century legal scholars never denied such intellectual heritage, in spite of their polemical verve against 18 th-century rationalism. ${ }^{50}$ Its importance was huge. It guided the construction of the systems of private law, whose premise was a sharp distinction between private law and procedure. However, the price to pay was to separate law from the real world, or in other words, from its historical dimension.

Legal historians answered such a call to purity with the distinction between internal and external history. The basic idea was simple. It dictated a basic method of exposition which assigned some topics to the internal sector and some others to the external sector. While its chief function was expository clarity, at the same time it introduced a purity code into the narration which defined precisely its object of study, insured its coherence and protected it from interferences. But where to locate such a boundary was far from being simple. This distinction implied a difficult question about the nature of law and its relationship with the wide world of indirectly related facts. And, while this preoccupation never abandoned 19th-century legal historians, they recurrently redefined where and how this distinction had to be drawn, and their textbooks routinely announced which side of legal history, either internal or external, they intended to contribute to. ${ }^{51}$

\subsubsection{The distinction between internal and external history: Gottfried W. Leibniz} The source of this distinction - if we are to believe Gustav Hugo's legal history manual (1790), which begins with an account of äußere und innere Rechtsgeschichte - is Gottfried Wilhelm Leibniz (1646-1716). Let us turn to this source. Leibniz spoke of historia iuris interna and historia iuris externa in his Nova methodus discendae docendaeque jurisprudentiae (1667). ${ }^{52}$ This work was intended to reshape the study of law on the basis of a coherent unity in which concepts and branches of law could converge, and indicated a set of methodological approaches - jurisprudentia didactica seu positiva, historica, exegetica, polemica seu controversiarum - and an observation: 'the historical study is either internal or external: the first enters into the

on this H Mohnhaupt, 'The Search for Legal Certainty and Security' in Lorraine Daston and Michael Stolleis (eds), Natural Law and Laws of Nature in Early Modern Europe: Jurisprudence, Theology, Moral and Natural Philosophy (Ashgate 2008) 73 at 85 and Caenegem, European Law, supra note 13, 68-69.

50 Gustave Hugo, Savigny's teacher, begins the first volume of his Civilistisches Magazin (1790) with an article on Leibniz, on which see R Berkowitz, The Gift of Science: Leibniz and the Modern Legal Tradition (Cambridge Mass 2005) 109-112.

51 Discussions of internal and external history are known by historians of science, on which see Steven Shapin, 'Discipline and Bounding: The History and Sociology of Science as Seen through the Externalism-Internalism Debate' (1992) 30 History of science 333-369. I am grateful to Dr Richard Serjeantson for bringing this article to my attention.

52 In this paragraph I am indebted to F Taranowski, 'Leibniz und die sogenannte äussere Rechtgeschichte' (1906) 27 Zeitschrift der Savigny-Stiftung für Rechtsgeschichte. Germanistische Abteilung 190. See also on this Emanuele Conte, Diritto Comune (2009) ch I, and Luigi Raggi, 'Storia esterna e storia interna del diritto nella letteratura romanistica' (1959) 1 Bullettino dell'Istituto di Diritto Romano 'Vittorio Scialoja' 199. 
substance of law, the other is an appendage (adminiculum)' ${ }^{53}$ By this he introduced an important separation: internal history charted the evolution of the principles of law; external history studied the origin and evolution of the sources of law and the social-political context out of which laws and institutions emerged. For example, it underscored the significance of the political history of Rome to understand public law ('historia Romana ... nostrorum temporum ad intelligendum ius publicum').

It seems worth noting that this distinction is one of the many fruits derived from a basic notion of classical rhetoric: the couple loci interni and loci externi. ${ }^{54}$ Popularised by Boethius and familiar to any law student until the eclipse of rhetorical learning during the 18th century, this distinction offered an ordering criterion by which any statement found its place according to the source of its argumentative power: internal arguments (loci interni) derived it from their rational coherence; external evidence (loci externi, sometimes conceptualised as testimonia), from the authority of external sources. This distinction, full of potential (see $\$ 3.2 .3 .5$ ), challenged other expository criteria such as, for example, the distinction in historical periods which we find in Jacques Godefroy's Manuale juris (1652) and the alphabetical order. ${ }^{55}$ Shifted to legal historiography, this distinction ascribed to internal history the evolution of the rational kernel of law; to external history its appendage (adminiculum) to be found in the social-political context.

2.3.2.3 Rewriting the boundary: Gustave Hugo The internal/external distinction had its heyday in the 19th century. It was a palpable presence in the textbooks published in this period. None of them omitted in its introductory pages to provide a brief account of its rationale and to declare which side of history, either internal or external, the book was about. But they understood it in a new way, following Gustav Hugo who rewrote the boundary established by Leibniz. Hugo suggested that external history studied the sources, that is to say, texts and empirical material (e.g. documents, inscriptions and coins), which he viewed as the external manifestation of the law. ${ }^{56}$ This idea implied a methodology deeply embedded in the critical evaluation of sources and was not insensitive to the overwhelming concern of his time for facts. Such impetus stamped a mark on historical inquiry. It upgraded history into a science that confidently

53 GF Leibniz, Nova Methodus, Part II. § 1. a29: 'Jurisprudentia historica est vel interna vel esterna: illa ipsam Jurisprudentiae substantiam ingreditur, haec adminiculum est, et requisitum'.

54 The source is Cicero's Topica, transmitted to medieval scholasticism through the commentary by Severinus Boethius (c. 480-524 AD).

55 For example, in the 17th century the alphabetic order of Johannes Bertachinus' legal vocabulary (Repertorium juris, late 15th century) was criticised for mixing internal and external loci: only the latter offered a reliable structure.

56 G Hugo, Lehrbuch, supra note 18, § 2, p 7. External history also includes the biographical study of jurists, beginning from T Diplovatiatio's De praestantia doctorum (1511) up to Savigny's History of Roman Law in the Middle Ages (1815-31), based on the idea that jurists are the witnesses of juristic experience. Today's biographical dictionaries can be referred to this literary genre. In the continental legal curriculum the internal/external history distinction is also reflected in the separation between the courses of Institutions of Roman law and History of Roman law. 
pictured the past, as Leopold von Ranke famously wrote, 'wie es ist gewesen' ${ }^{57}$ It also acknowledged a place for the hard sciences; chemistry, for example, contributed to Barthold Niebhur's discovery of Gaius' Institutes in 1816 by bringing to light hidden layers of writing. ${ }^{58}$ Another sector covered by external history was literary history (Literärgeschichte), which focused on the study of doctrinal works written upon the text of the law. One of the natural fruits yielded by this idea was a precise taxonomy of sources. A clear example is offered by Savigny in the Introduction to his treatise on possession (Das Recht des Besitzes, 1803). ${ }^{59}$ The first heading (Section I) collects the sources of Roman law, followed (Section II) by the historical literature built upon those sources (Literärgeschichte), which in turn is divided between Interpreten (the learned elaboration from Glossators up to the end of the 15th century) and Systematikers (from the 16 th century onwards).

Internal history, on the other hand, studied the evolution of private law. Sometimes the exposition was set out as a geographical map of the legal system, in which we find the legal field analysed in sections: the law of persons, property, succession, obligations, actions. Some other times it focused on just one institution, as in Savigny's treatise on possession mentioned above, perhaps the paradigmatic example of internal history.

How did the internal/external distinction come to be so highly influential in legal historiography? We need to consider that it was deeply intertwined with two assumptions deeply rooted in the 19th-century paradigm briefly sketched in these pages. In the first place, with the idea mentioned above that law can be conceptualised as a pure entity $(\$ 2.3 .2 .1)$. This expository device suited a methodological approach particularly keen on taxonomy; it mapped the legal world in a way that contributed to understanding law as an entity sealed off from interferences. ${ }^{60}$ The narrative could indeed include a wide range of facts but only some entered internal history. What could not be admitted - e.g. the sources, namely, jurists and texts - shifted to external history. Internal history acknowledged phenomena separated from a precise context, thus ideally related to any environment: alternatively, they had to be translated into intellectual forms suitable to speculative study. If so, jurists knew little of the legal world. They missed in fact two important aspects. The first was the process by which law is created, as what they knew about sources was part of external history, and they composed autonomous works, as Savigny masterfully did in his History of Roman law in the Middle Ages (1815-31); and the second was the idea of change in law, for all facts happening in the legal world were distilled to the pure forms congruent with an internal view. The real basis of this distinction was to include a range of legal phenomena into the narrative, but separated from true law.

Secondly, the impact of the internal/external distinction appears most clearly when we realise that it separated two aspects of the law: law-as-history and law-as-system

57 G Iggers, The German Conception of History, supra note 10, 63-89.

58 On which see generally, Wieacker, A History of Private Law in Europe, supra note 15, at 330-334; Reimann 'Nineteenth Century German Legal Science', supra note 11, at 873.

59 Friedrich Karl von Savigny, Das Recht Des Besitzes (1st edn, Giessen 1803) III.

60 See on this Giaro, 'Diritto Romano Attuale', supra note 28, at 77-80 and Riccardo Orestano, 'Ventotto pagine necessarie' in Diritto, incontri e scontri (Bologna 1981) 115 at 129. 
(§ 2.3.3.1). It would be reductive not to see the mark of Savigny's project of a legal science as at once historical and systematic. It was also congruent with the rising concern with the systematic arrangement of legal science, which had a place in the internal history side of the narration. The distinction triggered some other sharp separations: primarily between public and private law. Legal scholars agreed that public law, deeply intertwined with the contingent world of political institutions, was studied by contemporary history, and private law - the embodiment of perfect reason - was beyond the state and historical time. ${ }^{61}$ In sum, the internal/external distinction neatly drew a distinction between legal and non-legal history, between legal principles and the factors that generated them. In a word, between law and non-law.

Around the mid-20th century this distinction gradually disappeared from the lexicon of continental legal history - whereas it still has a place in current Anglophone scholarship. Civilians hesitated to think that a sector of law could be placed beyond historical time; they increasingly believed that legal concepts and doctrines do not belong to a natural order to be contemplated. ${ }^{62}$

\subsubsection{Historicism: Savigny - 'an organically progressive jurisprudence'}

\subsubsection{Historical legal science Another crucial assumption that guided 19th-century} legal historiography was the idea of historical time ('historicism'). ${ }^{63}$ We find its most revealing illustration in one of Savigny's programmatic writings, in which he posed a broad question: 'What is the relationship between past and present?' His reply is well-known - 'any epoch produces its own world in an indissoluble communion with the whole past' 64 - and this was the stepping stone for a view of law based on the co-operation of legal history and legal science: the first studied the evolution of law growing in time as 'an organically progressive jurisprudence'; 65 the second focused on

61 On this separation in early 19th-century Germany, see Hans-Peter Haferkamp, 'The Science of Private Law and the State in Nineteenth Century Germany' (2008) 56 Am J Comp L 667. See also the papers collected in N Jansen and R Michaels 'Beyond the State': Rethinking Private Law (Tübingen 2008).

62 Discussing this distinction, for example, in 1938 F Calasso wrote: 'la posizione reciproca dell'estrinseco e dell'intrinseco logicamente è tale da non consentire una separazione' in Calasso, Storia e sistema delle fonti del diritto comune, I, le origini (Milan 1938) 17-18. More recently, see, for example, Dirk Heirbaut's call for an 'integral legal history' in 'A Tale of Two Legal Histories' in Dag Michalsen (ed), Reading Past Legal Texts (Oslo 2006) 91.

63 On which see G Iggers, 'Historicism: The History and Meaning of the Term Historicism' (2016) 56 Journal of the History of Ideas 129 at 142.

64 Friedrich Karl von Savigny, 'Über den Zweck dieser Zeitschrift' (On the aim of this journal) (1815) 1 Zeitschrift Für Geschichtliche Rechtswissenschaft 2-3: 'Dieses also ist die allgemeine Frage: in welchem Verhältnis steht die Vergangenheit zur Gegenwart, oder das Werden zum Seyn? ... Ist aber dieses, so bringt nicht jedes Zeitalter für sich und willkürlich seine Welt hervort, sondern es thut dieses in unauflöslicher Gemeinschaft mit der ganzen Vergangenheit' ('This is the broad question: What is the relationship of past and present, or evolving with being? ... If so, every age does not produce its world by itself and arbitrarily, but in indissoluble communion with the whole past').

65 F von Savigny, Of the Vocation of Our Age for Legislation and Jurisprudence (A Hayward trans, London 1831 reprinted 1975) 182; Reimann, 'Nineteenth Century German Legal 
building a legal science shaped around a pure and abstract idea of Roman law. In a nutshell, he combined historical explanation and systematic construction. His chief ambition was to construct a superior model of legal science that comprised its own conceptual apparatus and methodology. 66 And he indicated it with the expression 'historical legal science', which is also the title of the journal he founded in 1815 (Zeitschrift für geschichtliche Rechtswissenschaft) to further his ambitious project.

This 'historical legal science' combined two contrasting endeavours. The first was history, and it is well-known the extraordinary and ground-breaking emphasis on history that Savigny claimed in his manifesto On the vocation of our age for legislation and jurisprudence (Vom Beruf unserer Zeit für Gesetzgebung und Rechtswissenschaft, 1814). He asserted that the law was essentially evolution in time and its entire fabric found coherence in its organic connection with its past. Savigny departed from the history propounded by Iusnaturalists and embraced the stirring view of history understood as the unfolding in time of the creative forces of the people. But then he added a second and contrasting element: systematic coherence. He believed that those immaterial forces developing in history required ulterior elaboration. They needed to be translated into an intellectual form by professional jurists in order to make them perceptible and capable of being known. Such science arose therefore from the co-operation of two components. One was history, the other was to be found in the systematic coherence offered by structures of formal thinking. It was precisely the fusion of those two approaches that upgraded legal science to a philosophy ("philosophy of positive law'). Thus the jurist, wearing the historian's hat, could describe an external reality, but then, wearing the philosopher's hat, focused on bringing to light its conceptual inner substructure. ${ }^{67}$ As we learn from Savigny's manifesto of 1814:

A twofold spirit is indispensable to the jurist; the historical, to seize with readiness the peculiarities of every age and every form of law; and the systematic, to view every notion and every rule in lively connection and co-operation with the whole, that is, in the only true and natural relation. ${ }^{68}$

To capture the full sense of this project we must look at the philosophical foundation implied in this project, which Savigny derived from Immanuel Kant. This author had been an important presence in Savigny's intellectual formation, if we are to believe the wish he expressed during his student years to become the Kant of legal science. ${ }^{69}$ Savigny followed Kant's recognition that knowledge begins from the apprehension of empirical data, but this was of little value without the legislative powers of the human mind, which filtered, organised and structured the raw data of experience. The

Science', supra note 11, at 877-878 n 158; ED Elliott, The Evolutionary Tradition in Jurisprudence' (1985) 85 Columbia Law Review 38; and generally Peter Stein, Legal Evolution: The Story of an Idea (Cambridge 1980).

66 A 'philosophy of positive law', according to Gustav Hugo, on which see Wieacker, $A$ History of Private Law in Europe, supra note 15, at 292-299.

$67 \quad$ Ibid, at 283-86.

68 Savigny, Of the Vocation of Our Age, supra note 65, at 64-65.

69 On which see Dieter Nörr, Savignys philosophische Lehrjahre. Ein Versuch (Frankfurt 1994). 
human mind had thus legislative powers to dictate intellectual forms upon empirical matter and thus upgrade them to a true science. Savigny shifted this idea to legal science: empirical experience is just a raw material that needs to be ordered into a superior unity of concepts and systematic coherence. ${ }^{70}$ The distinctive claim Savigny made was that legal history and legal science were thus united in a common pursuit; they could not be separated, as he wrote, 'as nobody can separate light from shadow':71 on one hand was the study of the particular viewed in historical evolution; on the other was the coherent construction of legal science.

Among those who have explored Savigny's intellectual project, for example Franz Wieacker, the consensus has been that this balance of history and system was indeed a fragile thing. Ideally, legal history and legal science proceeded hand in hand but in practice their union caused a sting which pierced the entire project. The contrast was particularly piquant in their object: history studied the empirical, the individual and the contingent that evolves in time; legal science studied an intellectual creature for the sake of a superior unity that only philosophy perceived, and which ultimately shaped it into a logical form. It is true that Savigny's project turned private law into a unified theory and generally legal science into a coherent doctrinal system, but it is nevertheless true, as Franz Wieacker observed, that 'the path toward the most utterly internal vision of law led to a legal science whose integral formalism turned it into the first non-historical jurisprudence of the whole history of law' ${ }^{72}$

The price to pay to ennoble legal science to the level of philosophy was to alienate it from the real world. It therefore comes as no surprise, as Wieacker remarked, that whole streams of thinking that came later - Rudolph von Jhering and the jurisprudence of concepts, Philippe Heck and the jurisprudence of interests, Hermann Kantorowicz and the free law movement, American and Scandinavian realism, legal sociology sought facts, experience, concreteness. ${ }^{73}$ Those scholars not only disliked any sort of abstractions and formalism, they refused to follow Savigny in his project of constructing a legal world 'in indissoluble communion with the whole past' (see above), and turned upside down the legacy received from the 19th century.

\section{COMPARATIVE LEGAL HISTORY}

\subsection{Antiformalism: Searching for a New Image of Law}

The decades 1930-60 saw a major turn in legal historiography. The clearest sign of a change of direction was the unprecedented impetus of the works published during those years to open new paths of research. Some pointed to new or previously overlooked

70 A History of Private Law in Europe, supra note 15, at 292-299 esp 294.

71 F Savigny, Review of Gustave Hugo, Lehrbuch der Geschichte des Römischen Rechts in Savigny, Vermische Schriften (1850), V, 2.

72 F Wieacker, 'Storicismo e formalismo alle origini della scienza giuridica moderna' in Studi in onore di Salvatore Pugliatti (Milan 1978) 893 at 909.

73 I owe this observation to F Wieacker, 'Storicismo e formalismo', supra note 72 . See on this also J Gordley, The Jurists, supra note 48, 275-312. 
subjects, such as the medieval ius commune and early-modern Superior Courts, others opened new fields of inquiry; for example, the history of criminal law, the history of public law and social history. ${ }^{74}$ The diversity of themes and methodologies alone contradicted the traditional view of historical research, unified by object and methodology. ${ }^{75}$ But such unrest was not limited to legal history. A new wind blew through the main field of history, and the Annales of Marc Bloch and Lucien Febvre, the Begriffsgeschichte of Reinhardt Koselleck and the Cambridge school of Quentin Skinner are only the most well-known names behind a general redirection of methods and approaches that pervaded historical research at large. Those directions of inquiry were many and diverse, but they all converged on a deeply felt disagreement with the intellectual commitments received from 19th-century historiography. While it is true that one swallow does not make a summer, it is precisely in those many voices, which in those years infused historiography with a new spirit of inquiry, that we find the signs of a new beginning.

Legal history is however a special case. As we have seen above ( $§ 1)$, this discipline cannot be separated from the way its scholars conceptualise their subject matter - the law. If we wish to understand how these scholars write the legal past, we need first to clarify their assumptions about what is law, who makes it and how. The main idea offered by Section 3 of this chapter is that to begin to understand how legal historiography evolved from the mid-20th century we first need to take into account a sweeping change of mind that invested legal thought in the period 1930-60. Those decades witnessed a turning point in European jurisprudence. Jurists saw the demise of intellectual commitments bequeathed from the 19th century and the beginning of another phase based on different premises. While the 19th-century jurist imagined law in the Janus-faced combination of legislation and doctrine described by Savigny (see above $\$ 2.2$ ), the period 1930-60 re-wrote that image. Some scholars started by launching a devastating attack on the absence of concreteness implied by the 19thcentury paradigm and went on dismantling the scaffolding of legal science. They reshaped the assumptions upon which they worked, and, most notably, they replaced the former protagonist, the legislator, who determined formal norms in abstracto for the purpose of regulating future events, with the judge. They considered that case law - as Karl Llewellyn stated: 'law found in decided cases and created by judges in the process of solving particular disputes' - was the true living law. ${ }^{76}$ The pendulum swung from the legislator to the judge.

A constellation of new assumptions accompanied this turn. To begin from the broadest ideas, we find a turn away from justice viewed as an ideal to be achieved by abstraction and deduction from first principles to the understanding that justice is best

74 On the ius commune see F Calasso, Medioevo del diritto (Milan 1954); on social history see G Iggers, The German Conception of History, supra note 10, 33.

75 For a general orientation see G Iggers, The German Conception of History, supra note 10 .

76 K Llewellyn, cited in Dawson, The Oracles, supra note 31, p. XIV. The view of the judge as 'living law' is an Aristotelian statement recurrent in ius commune texts (Nichomachean Ethics V 4, 1132 a 22). On this expression see also David Nelken, 'Law in Action or Living Law? Back to the Beginning in Sociology of Law' (1984) 4 Legal Studies 157. 
served when it is determined case by case. ${ }^{77}$ Other jurists fixed their attention on judicial procedure and showed its previously overlooked relevance. Others concentrated their efforts on the appropriate models of reasoning to make that instrument work, such as reasoning with probable arguments, paradigms, cases and examples (§ 3.2.3.5). Legal scholars felt constrained by the narrow boundaries of their discipline and explored other normative dimensions. They tried to reconnect them to the law as they believed that in its evolution law had been isolated, and consequently impoverished. They moved in diverse directions and turned to a myriad of dimensions aimed at a wider notion of law, questioning the line between law and non-law.

A fitting name for this range of ideas is antiformalism. It can be more appropriately viewed as an intellectual ferment rather than a fixed system of ideas, and the scholars who endorsed those positions cannot be said to have been homogeneous. But they all repudiated the paradigm that dominated legal academia. At the heart of their endeavours was the dislike of, and often the outspoken attack on, a range of ideas whose kernel was the 'formalism' implicit in Kant's idea of science, based on a dualism of matter and form, which Friedrich von Savigny placed at the basis of his project of a legal science depurated from external contaminations $(\$ 2.2)$. They fixed their attention on that boundary. They abhorred the idea of law understood as a depurated knowledge and challenged the connected notion of a dividing line that separated the purely legal from the real world. They refused to think of law as a closed system, finding that conception too narrow and abstract, and explored ways to broaden it. ${ }^{78}$

Among antiformalism's many proponents we find a group of emigrés who fled Germany for the UK and the US, beginning with Hermann Kantorowicz (1877-1940), who contrasted 'formal law' with what he liked to call 'free law'. Indeed, it may be argued that some of these scholars' critical positions show a line of descent that goes back to Rudolf von Jhering (1818-92) and other jurists of late-19th-century Germany, ${ }^{79}$ but it is important to point out that, while those earlier utterances did not transcend the boundary of German scholarship, the emigrés spoke to the broader audience of an intellectual environment which by then extended internationally, following the European intellectual leadership shifting from Germany to England. ${ }^{80}$ At the same time they

77 See for example the revival of case-based moral reasoning in AJ Jonsen and S Toulmin, The Abuse of Casuistry: A History of Moral Reasoning (Berkeley 1988). See also Michael Walzer, Spheres of Justice: A Defence of Pluralism and Equality (Oxford 1983).

78 Wieacker, A History of Private Law in Europe, supra note 15, at 328 and 295. In this chapter I avoid 'post-modernism' because of its vagueness. If a reference to modernity is necessary, the historical orientation which pervades this intellectual stream would rather suggest the term 'pre-modernism'.

79 For example, Philippe Heck, Ernst Fuchs and Ernst Stampe, who however had a minimal echo outside Germany. On them see Gordley, The Jurists, supra note 48, 275-312. On Jhering see H Hofmann, 'From Jhering to Radbruch: On the Logic of Traditional Legal Concepts to the Social Theories of Law to the Renewal of Legal Idealism' in D Canale, P Grossi and H Hofmann (eds), A Treatise of Legal Philosophy and General Jurisprudence. Vol 9: A History of the Philosophy of Law in the Civil Law World, 1600-1900 (Dordrecht, 2009), p. 301, esp. 306-307.

80 D Ibbetson, 'Hermann Kantorowicz and Walter Ullmann' in J Beatson and R Zimmermann (eds), Jurists Uprooted (Oxford 2004) 269. This theme is currently studied by the project led by Kaius Tuori, 'Reinventing the Foundations of European Legal Culture 1934-1964'. See 
reformulated their scholarship, deeply rooted in their original tradition, for the new intellectual setting. They tended to view the English common law as the perfect example of judge-made law and a superior model to contrast with continental law, whose strictures they attributed to its quest for systematic coherence. And some scholars carried the argument even further, declaring that a new start could be achieved by uncovering, as Fritz Pringsheim said, the 'inner relationship' that linked civil law and English common law. ${ }^{81}$ Such an approach has of course proved an extremely fruitful one for comparative legal historians.

It would be misleading to overlook the range of diverse intellectual strands that contributed to such intellectual ferment, and, even more importantly, the family resemblance which runs through them, although developed in distant European areas. In the Nordic countries, for example, we find Scandinavian realism and Axel Hägerström, who sought an alternative explanation to the basis of private law; ${ }^{82}$ in England, we find the fallibilism of those (e.g. Karl Popper, Isaiah Berlin, Michael Polanyi) who exposed the epistemological fragility of first principles, in France, the neo-Thomism of Jacques Maritain and Michel Villey, who revived ethics in view of a broader understanding of law, and the École de Bruxelles of Chaïm Perelman, whose main concern was to uncover the relevance of classical rhetoric to current forms of legal reasoning. Their dislike for a paradigm that in their eyes had lost credibility contributed to a deep turn in the European legal tradition.

Although the antiformalist wave of the 1930-60s presents us with a variety of intellectual strands, so diverse as to contradict any effort to summarise it under one simple formula, it would be misleading to view it as a borderless constellation of ideas. Some jurists felt compelled to keenly separate their project from that pursued on the other side of the Atlantic by another version of antiformalism offered by American legal realism. As is well known, the early decades of the 20th century saw in the US the legal realist protest against the conceptualism that dominated legal academia. A host of leading scholars (Karl Llewellyn, Jerome Frank and Max Radin, among others) began by remarking that formal law counted only little and was indeed just one element in decision-making. Starting from the empirical observation of how judges effectively worked, they noted that, because of the law's unavoidable indeterminacy, as Brian Leiter wrote, 'in deciding cases, judges respond primarily to the stimulus of the facts'. ${ }^{83}$ The main idea was that decisions came from a process chiefly concerned with facts, and everything else, as Lon Fuller famously asserted, was 'Reified Abstractions,

also for an overview U Mattei, 'Why the Wind Changed: Intellectual Leadership in Western Law' (1994) 42 Am J Comp L 195.

81 F Pringsheim, 'The Inner Relationship Between English and Roman Law' (1935) 5 Cambridge Law Journal 347.

82 Axel Hägerström, Inquiries into the Nature of Law and Morals (CD Broad trans, Stockholm 1953); see also Heikki Pihlajamäki, 'Against Metaphysics in Law: The Historical Background of American and Scandinavian Legal Realism Compared' (2004) 52 Am J Comp L 469.

83 Brian Leiter, 'Rethinking Legal Realism: Toward a Naturalized Jurisprudence' (1997) 76 Texas Law Review 267, 269. On realism see generally Neil Duxbury, Patterns of American Jurisprudence (Oxford 1997) and Brian Leiter 'Positivism, Formalism, Realism' (1999) 99 Columbia Law Review 1138. 
Omnibus Concepts, and Metaphors Masquerading as Facts'. ${ }^{84}$ The moral was that only the latter were the proper subject of legal study.

It is true that both American and European antiformalisms fixed their attention on formal law's unavoidable indeterminacy, with the effect of eroding its immaterial majesty. However, as Kantorowicz stressed, the first point that needed to be emphasised in American legal realists' arguments, was the extent to which they considered the empirical approach to be their chief centre of attention. In his eyes such single-minded concern with facts blurred the line between law and natural sciences, and this was a perilous step which he was unwilling to take. ${ }^{85}$ Today's extension of economic analysis into the province of law makes those arguments worthy of being considered again $(\S 3.2 .2 .3)$.

Antiformalism is one of the traits of today's legal thinking. Some of the seminal ideas that have fuelled original research in legal studies in the last decades, and are today shared as an obvious truth - expressed as 'to place law in context', 'to think outside the doctrinal box' and in the general distaste for abstract theorising - are the fruit of the antiformalist turn of the 1930-60 period.

\subsection{Three Assumptions Guiding Comparative Legal History}

The decades 1930-60 saw the publication of a host of works self-styled as comparative legal history. Among them we find the works published by John Dawson, Gino Gorla, Robert Millar and others. Looking back at them today, we realise that they can be placed at the beginning of a style of writing legal history in balance between a historical and comparative approach: on one hand they are genuinely historical witness the sources used for example in John Dawson's Oracles of the Law - and on the other they build upon an in-depth knowledge of foreign law. They also announce a leaning towards today's overwhelming concern with the history of judicial procedure. ${ }^{86}$ Yet, what makes their contribution distinctively original is less in their sporting the label of a historical and comparative approach, already known in the 19th century, but

84 Cited in Duxbury, Patterns of American Jurisprudence, supra note 83, 223.

85 The point was made by Hermann Kantorowicz in his 'Some Rationalism about Realism' (1934) 43 Yale Law Journal 1240.

86 Among which John Dawson, The Oracles of the Law (Cooley lectures 1959, Ann Arbor 1968); Robert Wyness Millar, Civil Procedure of the Trial Court in Historical Perspective (New York 1952); and the many studies by Gino Gorla, including Il contratto: problemi fondamentali trattati con il metodo comparativo e casistico (1954), 'I Grandi Tribunali italiani fra i secoli XVI e XIX: un capitolo incompiuto della storia politico-giuridica d' Italia', in Quaderni de 'Il foro italiano' (suppl Il foro italiano, 1969, c 629). See the volumes of the Recueils de la Societé Jean Bodin pour l'histoire comparative des institutions (Bruxelles 1936-), whose general project is discussed in Jean Gilissen, 'Histoire comparée du droit: l'expérience de la Société Jean Bodin' in M Rotondi, Buts et méthodes du droit comparé, Inchieste di diritto comparato, vol 2 (Padua 1973) 256-297; the series Comparative Studies in Continental and Anglo-American Legal History, H Coing and K W Nörr (eds) (Berlin 1998-); and the series L'Educazione Giuridica, Ricerche sul Processo, Testi e documenti per la storia del processo, Alessandro Giuliani and Nicola Picardi (eds) (18 vols, Padua and Milan 1975-1996). 
in their premises. ${ }^{87}$ This chapter argues that it would be misleading to separate their methodological approach from the antiformalist redirection of legal science which occurred in the period 1930-60, and, more specifically, it contends that their main intention lies in an anti-dogmatic stance. For example, if we turn to Gorla's work on contracts (1954) we realise that this work was not intended as a descriptive account of the similarities and differences between continental and English contractual regimes, but to explore other ways to explain the contractual bond. Its real impact came from keeping provocatively silent on the hegemonic account bequeathed from 19th-century Pandectism. ${ }^{88}$

My aim in what follows will be to show that the distinctive character of the rise of a historical-comparative approach can be clarified by looking at the broad renovation that crossed legal academia at large. This turn meant a redirection of legal historiography. As we have seen $(\S 1)$, the writing of history requires a criterion that separates what is relevant from what is not, without which the historian would not know what he or she is looking for. During those years some jurists worked out a set of views about the nature of law in the form of a critical reaction to the received understanding. They stood back from the intellectual commitments bequeathed to them by the 19th century and, starting from other premises, they contributed to replacing an image of law that saw codification and doctrine as the chief ideals to be fulfilled, with the commitment to the idea that justice is best served by the judge who makes decisions case by case. Their focus shifted from substantive law to procedure, from statutory law to case law, from abstractions to facts. Similar assumptions were reiterated by legal historians. They saw themselves not only looking at an alternative understanding of law, but at another way to write its history. With those reformulated assumptions they determined a new beginning. Broken traditions cannot be mended - 'as if we had to repair a torn spider's web with our fingers', as Ludwig Wittgenstein wrote. ${ }^{89}$

In what follows I will indicate three broad directions that counteracted the 19thcentury paradigm in three specific instances: (i) the concern with other modes of normativity that contradict the exclusive concern with black-letter law ('textualism') (\$3.2.1); (ii) the attack launched on a theory-centred approach to the law ('purity') (\$3.2.2); and (iii) the turn away from an explanation of historical time in terms of

87 A chair of Histoire générale et philosophique des législations comparées was established at the Collège de France in 1831, to which was appointed Jean-Louis-Eugène Lerminier (1803-1857), author of a Histoire des législations comparées (1837), on which see F Audren and G Navet, 'Note sur la carrière d'Eugène Lerminier au Collège de France (1831-1849)' in (2001) 4 Revue d'Histoire des Sciences Humaines 57. On the combination of universal legal history and comparative law in Joseph Kohler (1849-1919), and other comparative works, see HC Gutteridge, Comparative Law: An Introduction to the Comparative Method of Legal Study \& Research (Cambridge 1946) 11-22. More recently, see Gábor Hamza, 'Comparative Law and Antiquity in the Trends of Legal Humanism and Natural Law' (2007) 47 Acta Hungarica 279 and the broad overview offered in Charles Donahue, 'Comparative Law Before the Code Napoléon' in Reimann and Zimmermann, Oxford Handbook of Comparative Law, supra note 3, at 3 .

88 I am grateful to Professor Antonio Padoa-Schioppa for a personal recollection on this subject.

89 L Wittgenstein, Philosophical Investigations, § 106, in A Kenny, The Wittgenstein Reader (Oxford 2006) 63. 
cumulative development ('historicism') (§ 3.2.3). I hope to indicate the pervasive extent to which such assumptions about the law set the terms for other ways to write its history.

\subsubsection{Against textualism}

3.2.1.1 'Law contains no less lacunae than words' One of the first assumptions to be questioned by the antiformalist wave of the 1930-60s was textualism, the idea that legal authority is conclusively expressed only in a final and conclusive codified text (§2.3.1.1). Some scholars stated that any hope of achieving such a formally enacted text was doomed to failure because of the inevitable presence of gaps that judges must fill in. Their point was that textual law was inherently incomplete. Such arguments desacralised the majesty of codes.

This position found its most eloquent spokesman in Hermann Kantorowicz, who in his Battle for Legal Science (Der Kampf um die Rechtswissenschaft, 1906) launched a superbly confident attack on textual law. His argument took as its starting point an analysis of legal language. He asserted that the impossibility of creating a perfect codified text arose from the fact that the legislator cannot determine univocally the meaning of all words, nor produce a self-referential technical language. Its functioning was in fact highly dependent on terms with no determinate meaning - such as Treu und Glauben, force majeure, necessity, required diligence, abuse of law, tacit declaration, compensation for damage. As he put it succinctly, 'law contains no less lacunae than words'. In presenting his position in these terms, the main implication was that the judiciary had an active role in filling the gaps of the law. Thus, textualism was methodologically wrong and the completeness and coherence of the law amounted to no more than a comforting myth. If Savigny made the fortune of the law professor, with Kantorowicz the new star became the judge.

3.2.1.2 Against textualism: the reappraisal of ordinary language Other arguments against textualism came from the study of ordinary language. Some scholars were aware that one of the main implications of breaking free from a textual approach was the need to find a new linguistic philosophy. They realised that the premise of codified law, being a collection of logically ordered statements, was the conscious possession of a formal language. In fact, the rise of codifications went in hand with the fashioning of a specific language that appropriately conveyed the legislative intention. It had to be clear, unambiguous and free from gaps that need to be filled by interpreters. Beginning from Thomas Hobbes' war on the 'equivocall signification of words' down to Jeremy Bentham's attack on fictions, ${ }^{90}$ legislators found an ally in the crafters of a perfect language, as only a clear text is immune from interpretation (in claris non fit interpretatio). This being so, one of the main conditions to successfully steering away from such intellectual heritage was to search for another language functional to a broader idea of normativity.

90 On which see respectively: Quentin Skinner, Reason and Rhetoric in the Philosophy of Hobbes (Cambridge 1996) 345; and Naomi Maya Stolzenberg, 'Bentham's Theory of Fictions: A Curious Double Language' (1999) 11 Cardozo Studies in Law and Literature 223. 
To see how continental legal scholars arrive at their conclusion, we need first to consider the treasure chest of arguments against the primacy of formal language to be found in the investigations on ordinary language carried out by some language philosophers (JL Austin, the 'second' L Wittgenstein, G Ryle, H Price and others) at Oxford in the 1950s. They attacked a view of linguistic philosophy narrowly focused on the cognitive errors caused by unclear or loose language. They specifically contested the premise that the only permissible presence in knowledge is clarity. By doing so they not only undermined the purpose of single mindedly defining the proper ways to produce clear and unambiguous concepts, they went on to advance the distinctive claim that restricting language to the formally true jettisoned a world of ideas expressed only by ordinary language or verbally unformulated practices. In a nutshell: "clarity is not enough'. ${ }^{91}$ Such bold claims were heard on the continent and were persuasive regarding other ways of thinking about legal language. The argument in favour of this perspective takes at its starting point the recognition - often found in Roman law texts - that language is an unfaithful servant because of the mismatch between words and things; this misalliance was indeed inevitable given the paucity of words in regard to things. ${ }^{92}$ Legal scholars had therefore no other resource than to use metaphors to communicate ideas. Such language could not be tested by formal logic, but was nevertheless operative and, what is more, had always contributed to the formation of legal vocabulary (e.g. the sources of law, extinguishing an obligation, legal transplants).

This perspective was championed by the philosopher John L Austin in his insistence that: "[i]t was for too long the assumption of philosophers that the business of a "statement" can only be to "describe" some state of affairs, or to "state some fact", which it must do either truly or falsely". ${ }^{93}$ Legal scholars were pleased to see that what Austin had in mind was legal language. They realised that statements such as 'I hereby pronounce you husband and wife' performed at a wedding, or 'I bequeath' as occurring in a will or promises, although neither true or false in terms of logic, yet in the appropriate circumstances were wholly effective; most of the law is in fact operative through such statements. To study ordinary language contributes to deviating from the exclusive concern with black-letter law. It indicates modes of normativity based on unwritten rules, precedents and examples, and advocates that the line that separates technical from ordinary language is thin. In this way, it discourages the pursuit of any formalised legal language. Current legal scholarship tends to agree that formal language covers just a limited sector of law, and other dimensions of normativity, otherwise

91 HH Price, 'Clarity is Not Enough' (1945) 19 Proceedings of the Aristotelian Society 1 and in HD Lewis, Clarity is not Enough: Essays in Criticism of Linguistic Philosophy (London 1963); on which see generally HJ Glock, What is Analytic Philosophy? (Cambridge 2008) $168-174$.

92 Aristotle, De sophisticis elenchis, 165a14-16: 'There are more things than words', and Ulpian, in D.19. 5. 4: 'there are more types of agreements than terms able to define them' (ut plura sint negotia quam vocabula). On metaphors see recently, David Nelken, 'Legal Transplants and Beyond: Of Disciplines and Metaphors' in A Harding and E Örücü (eds) Comparative Law in the 21th Century (London 2002) 19-34.

93 JL Austin, How to do Things with Words (London 1962) 1. 
silent, are expressed by metaphors, aphorisms and maxims. ${ }^{94}$ The growing understanding is that black-letter law is just a small window on the legal world.

\subsubsection{Against purity: law is a hybrid}

3.2.2.1 Beyond theory-centred law I now turn to the second assumption questioned by the antiformalist wave of the period 1930-60 - 'purity' - which arises from the 19th-century belief that law can be isolated from the context in which it operates, and can therefore be studied as a pure entity free from contaminations $(\S 2.3 .2 .1)$. Current legal scholarship tends to claim just the opposite. Legal scholars are inclined to stress the hybridity, the porosity, the mixtures, the contamination, in a word, the understanding that law has no clear boundaries. ${ }^{95}$ In diverse ways they attack its main implication: a theory-centred idea of law.

It seems worth noting that such an anti-theoretical position crossed the broader intellectual landscape of post-World War II. ${ }^{96}$ The main idea was that theory seemed a futile or even meaningless enterprise. We find for example the political philosopher Michael Oakeshott (1901-90) writing that 'theory is the stepchild of practice', ${ }^{97}$ and that 'first principles' are just distilled from practice. Practical knowledge attracted instead more attention, and some scholars described it as an independent body of knowledge logically prior to speculation; the philosopher Gilbert Ryle (1900-76) called it 'knowing how', the economist Michael Polanyi (1891-1976), 'tacit knowing', and Michael Oakeshott, 'traditional knowledge'. ${ }^{98}$ They believed that theory produced only unproductive and sterile knowledge.

Other scholars believed that the most effective alternative to theory-centred philosophies was offered by history - as the philosopher José Ortega y Gasset asserted, 'man does not have a nature, but a history'. 99 The extraordinary amount of attention fixed on Giambattista Vico (1668-1744) in the mid-20th century as the avatar of a fresh historical sense, testifies to such an attempt. ${ }^{100}$ At the heart of such a revived constellation of ideas is the suggestion that thinking historically counteracts theory's primacy. This idea is further strengthened by the conviction that history offers a mode

94 See for example Peter Stein, Regulae Juris: From Juristic Rules to Legal Maxims (Edinburgh 1966), David Daube, Forms of Roman Legislation (Oxford 1956).

95 See Seán Donlan, 'To Hybridity and Beyond: Reflections on Legal and Normative Complexity' in V Palmer, A Koppel and M Mattar (eds), Mixed Legal Systems, East and West (Farnham 2015); and generally, William Twining, Law in Context: Enlarging a Discipline (Oxford 1997).

96 Ex aliis, see Robert Venturi, Complexity and Contradiction in Architecture (New York 1966).

97 Cited in J Gray, Liberalisms: Essays in Political Philosophy (London 1991) 203.

98 G Ryle, 'Knowing How and Knowing That' (1946) 46 Proceedings of the Aristotelian Society 1; M Polanyi, Personal Knowledge: Towards a Post-Critical Philosophy (Chicago 1958); M Oakeshott, Rationalism in Politics (London 1962), echoed in Patrick Glenn's hesitation in offering a theory of tradition in Patrick Glenn, Legal Traditions of the World (Oxford 2014) 3-4.

99 José Ortega y Gasset, 'Historia como sistema', in Obras completas, Vol. 7 (Madrid, 1983), p. 41: 'el hombre no tiene naturaleza, sino que tiene ... historia'.

100 See Michael Mooney, Vico in the Tradition of Rhetoric (Princeton 1985) and Peter Burke, Vico (Oxford 1985). 
of knowing that contradicts the belief that the legal world can be conceived as perfect, in the same way as the world of nature. There is no nature to contemplate for historians. ${ }^{101}$ All they have is the belief that human learning grows by posing questions and attempting answers. They also know that to investigate the institutions, concepts and doctrines of the social world produces a fully effective knowledge, as this is a man-made world and thus knowable, according to Vico's verum ipsum factum principle ('the true and the made are convertible into each other'). ${ }^{102}$

3.2.2.2 The primacy of controversy One of the clearest signs of the demise of a theory-centred idea of law is the turn to procedure and evidence that occurred in the early 20th century. Keeping in mind the distinction that divides the legal world into substantive law and procedure (or law and fact) we realise that, while 19th-century legal science prioritised the first and despised the second, the early 20th-century legal scholarship reversed the trend prioritising procedure and evidence. Legal scholars found a largely understudied field of inquiry, overshadowed by the almost exclusive concern with private law; a field which in England has won some serious consideration only recently. ${ }^{103}$ Such a shift of attention implies the recognition that at the heart of law is the controversy, not the system of subjective rights waiting to be enforced and executed, and that the whole fabric of law starts from disputed facts and the judicial ways to settle them. At its source we find once again Rudolf von Jhering who, fighting against the dominant paradigm of will theory in private law, argued that this sector can be analysed beginning from the side of procedure and evidence. He said that in legal practice any contested claim hinges on the question of evidence'. ${ }^{104}$ Such arguments opened another stream of research aimed at a better understanding of the question of fact. It favoured the study of legal reasoning, the revival of rhetoric and of a constellation of other subjects finalised to the rise of a new evidence scholarship, with its interdisciplinary implications. As William Twining said, '[t]he serious study of reasoning in regard to disputed matters of fact is at least as important and can be at least as intellectually demanding as the study of reasoning in respect of disputed questions of law'. In short, jurists must learn to take facts seriously. ${ }^{105}$

101 I owe this observation to E Perreau-Saussine, 'Quentin Skinner in Context' (2007) 69 Review of Politics 106-122 at 118.

102 This principle is invoked in the Trento manifesto of comparative law, third thesis (1987) cited in R Sacco, 'Legal Formants: A Dynamic Approach to Comparative Law (I of II)' (1991) 39 Am J Comp L 1 at 26 note 29.

103 JA Jolowicz, 'Lo studio del diritto processuale civile in Inghilterra: Perché così scarno e così in ritardo?' (1998) 52 Rivista trimestrale di diritto e procedura civile 871, and generally the essays collected in W Twining, Rethinking Evidence: Exploratory Essays (Cambridge 2006).

${ }_{104} \mathrm{R}$ von Jhering, 'Du rôle de la volonté dans la possession. Critique de la méthode juridique régnante' in Études complémentaires de l'Esprit du droit romain ( $\mathrm{O}$ de Meulenaere trans, Paris 1891) III, 125.

105 W Twining, 'Taking Facts Seriously' in W Twining, Rethinking Evidence: Exploratory Essays (Cambridge 2006) 14-34. See also Tomasz Giaro, 'Knowledge of Law as Knowledge of Facts: The Roman Experience' in T Giaro (ed), Roman Law and Legal Knowledge: Studies in Memory of Henryk Kupiszewski (Warsaw 2011) 215. On the intellectual context of the 20th-century revival of Aristotle's Rhetoric see A Giuliani, 'L'altro Aristotele' (2010) 3 Sociologia 125. 
The rise of comparative legal history boosted this turn. Beginning from the earliest researches pursued in the 1950s, most notably by John Dawson and Gino Gorla, legal scholars stressed the significance of judges and courts in the making of early-modern law. By doing so, they contributed to establishing a field of inquiry that today has the lion's share of research projects of comparative legal history. ${ }^{106}$ They also eroded the hegemonic presence of private law as the major focus of historical research. Its effect was felt at a further level. It offered alternatives to the viewpoint of the private law scholar, who tended to replicate in the past his familiar conceptual world, sometimes worked out with considerable attention to detail, fuelling a search for dogmatic categories. As Sir John Baker observed:

We have ... become interested in contract and tort to an extent which lawyers before the 19th century would have thought absurd - not because either was unimportant, but because litigation in those areas was resolved by applied common sense and required only practical knowledge. We find ourselves poring over a tiny core of materials, reading between the lines to uncover the unspoken assumptions about questions we address everyday in our own law schools. Some leading cases ... were not about substantive law of contract and tort as we know it, but about procedure and pleading. But I would suggest that we cannot properly understand anything of the earlier common law unless we understand the dominance of form and procedure, and perceive the limitations which the procedural framework placed on the questions which could be asked at the time and therefore on the questions which can be answered now. ${ }^{107}$

The new historiographical wave argued that it is not enough to study black-letter law. It showed that, while the study of legal norms was essential for the legal historian, it was equally important to understand the process by which they are applied to facts. The point was made by Helmut Coing in 1985, asserting that a meaningful investigation of the ius commune implied a detailed study not only of the formal sources of law but also of the methods and ways of reasoning by which rules are applied. ${ }^{108}$

As we analyse and reflect on this broader path of research, we realise that to disagree with a theory-centred idea of law, while on the one hand leads to a more complete understanding of the legal phenomenon, on the other hand, as Alain Wijffels warned in 1985, it requires extending the research into a terra incognita. ${ }^{109}$ But that territory was part of legal thinking before the rise of the 19th-century paradigm. When legal scholars

106 See e.g. the titles in the series Comparative Studies in Continental and Anglo-American Legal History published by Duncker \& Humblot, Berlin.

107 John Baker, 'Reflections on "Doing" Legal History' in Anthony Musson and Chantal Stebbings (eds), Making Legal History: Approaches and Methodologies (Cambridge 2012) 7-17.

108 Helmut Coing, Europäisches Privatrecht, Bd. 1: Älteres Gemeines Recht (1500-1800) (Munich 1985) 15: 'Ein tieferes Verständins des Rezeptionsvorganges und des älteren gemeinen Rechtes ist nur möglich, wenn man auf die Eigenarten der Quellen des rezipierten Rechtes und auf die Methode eingeht, mit welcher die Juristen seit der Wiederbelebung der Rechtswissenschaft an diese Quellen herangetreten sind' (emphasis in the original text).

109 Alain Wijffels, Qui millies allegatur. Les allégations du droit dans les dossiers du Grand Conseil de Malines (Leiden 1985) I, 454-455. See the study of the 'styles of legal thought' advocated by William Ewald 'as an intermediate position broader than textualism, but less broad than full sociological contextualism' in William Ewald, 'Legal History and Comparative Law' (1999) 7 Zeitschrift für Europäisches Privatrecht 553 at 556. 
moved in the direction of a theory-centred idea of law they also restricted the province of law and at the same time impoverished it by erecting boundaries to keep it uncontaminated. Among those who in the period 1930-60 felt such constraints, the consensus was to reopen a dialogue with disciplines that a theory-centred law had made redundant. Their efforts spread in several directions. One of them was to revive some Aristotelian books that conflicted with the pathos of codification: the works on Rhetoric, Ethics, Politics and Economics. ${ }^{110}$ The aim was to reconstitute a dialogue between law and those disciplines for a better understanding of the legal world, and by doing so, to recapture its former complexity.

The first book is Aristotle's Rhetoric, revived by the nouvelle rhétorique mouvement of Chaïm Perelman, whose main concern was to explain judicial reasoning in a way that, by showing the rational dimension of truth-seeking in the question of fact, supported the autonomy of the judge and in turn contradicted the hierarchical structure of the continental judiciary. ${ }^{111}$ Another dimension to be added is that legal reasoning is a field of study unaffected by the boundaries of state-law. More specifically, a concern with legal reasoning is the premise for understanding legal traditions that recognise a place for the interpretive elaboration of the law; one example is Islamic law (shari'a), whose sources include doctrinal consensus (ijma), logical principles and analogical reasoning (qiyas). ${ }^{112}$

The second Aristotelian book that received attention was the Politics, the work that suggested the view of the community structured around a political order alternative to the state. As Quentin Skinner showed, this work was part of a constellation of ideas revived in the medieval communes of Central and Northern Italy and focused on active citizenship and civic virtues, suggesting that this was the intellectual context in which Bartolus of Saxoferrato wrote his well-known tracts On Tyranny, On City Government and On Guelfs and Ghibellines. ${ }^{113}$ However, if those insights were part of a general methodological re-orientation experienced within the field of the history of political thought, the legal historians' impetus in rethinking the world of medieval communes during the 1930-60 period was one of the most characteristic and influential turning

110 The relation between Ethics, Economics and Politics is stated in Thomas Aquinas, In decem libros Ethicorum Aristotelis ad Nicomachum expositio (Turin 1934) 4: 'moralis philosophia in tres partes dividitur. Quarum prima considerat operationes unius hominis ordinatas ad finem, quae vocatur monastica. Secunda autem considerat operationes multitudinis domesticae, quae vocatur oeconomica. Tertia autem considerat operationes multitudinis civilis, quae vocatur politica', cited in J Kraye, Cambridge History of Renaissance Philosophy (Cambridge 1988), p. 304 ('Moral philosophy is divided in three parts. The first, called monastic (or ethics), focuses on the operations of the solitary individual as ordered to an end. The second, called economics, deals with the operations of the domestic community. The third, called politics, focuses on the operations of the civil association').

111 Chaïm Perelman and Lucie Obrechts-Tyteca, Traité de l'argumentation, la nouvelle rhétorique (Paris 1958).

112 P Owsia, 'Sources of Law under English, French, Islamic and Iranian Law: A Comparative Review of Legal Techniques' (1991) 6 Arab Law Q 33 at 41.

113 Quentin Skinner, The Foundations of Modern Political Thought (Cambridge 1978) I, 50-51 and PO Kristeller, Renaissance Thought I. The Classic, Scholastic, Humanistic Strains (New York 1961) 36, and on this general theme see Q Skinner, Liberty Before Liberalism (Cambridge 1998). 
points of the discipline. Some legal historians, Francesco Calasso (1904-65) foremost among them, saw a legal world ordered around a plurality of institutions and laws which were ordered and combined in the overarching macrostructure of the ius commune. ${ }^{114}$ Such a construction was evidence of a law without the state. Calasso stressed also the originality of ius commune's learned constructions; in his mind they closely reflected the uniqueness of the medieval legal world and were inextricably bound to it. Their law could not be separated from the historical setting of the medieval world, which produced, as one of its most characteristic fruits, its own law. Such ius commune was, in Calasso's phrase, 'il medioevo del diritto'. Such a view sharply opposed the Romanists, who saw in medieval law an indistinguishable phase in the broader evolution of Justinian's law. The impact of the ius commune, viewed as a law without a state and alternative to the state-centric conceptions inherited form the 19th century, could not be deeper.

Thirdly, the Nicomachean Ethics is the work that brought to light a substrate of virtues in human action, and whose Book $\mathrm{V}$ on justice is one of the essential texts in the making of the Western legal tradition. As James Gordley and Wim Decock demonstrated in their historical studies of contracts, the private law scholar can ignore that substrate at his peril. ${ }^{115}$

Fourthly, the (pseudo) Aristotelian work on economics (Oiconomica) offers an understanding of exchanges in a community beginning from household management. This work was important for those scholars who tried to reconstitute a dialogue between law and economics. The point they pressed was to revive a perspective that vanished with the establishment of Economics (previously known as Political Economy) as an autonomous academic discipline in the mid-19th century. The highlight of their efforts was the revival of Adam Smith, known as the father of Economics, but also as a moral philosopher who had a place in the intellectual landscape of his time with his Theory of Moral Sentiments (1759) and a teacher of Jurisprudence. ${ }^{116}$

The moral to be gathered from those enterprises is that scholars from different fields set themselves the task of recapturing a unitary view of law that studied individuals in the diverse roles they had in their social world. Legal reasoning, for example, focused on their arguing about the truth of a statement; ethics, their acting more or less virtuously; politics, their interacting within a community; economics, their producing and exchanging wealth. One consequence of becoming attuned to such a broader idea of law is that legal scholars may be led to question the heuristic value of understanding contract law by analysing definitions (e.g. Code Napoléon, art. 1101) when this is a phenomenon that involves questions of justice and fairness, a system of signs to

114 F Calasso, Medio evo del diritto (Milan 195), on which see P Costa, "Ius commune", "ius proprium", "interpretatio doctorum": ipotesi per una discussione' in A Iglesia Ferreirós (ed), El dret comú i Catalunya. Actes del IV Simposi Internacional, Barcelona, 27-28 de maig de 1994 (Barcelona 1995) 29-42.

115 James Gordley, The Philosophical Foundations of Modern Contract Doctrine (Oxford 1991); Wim Decock, Theologians and Contract Law: The Moral Transformation of the Ius Commune (Leiden 2012).

116 Adam Smith, Lectures on Jurisprudence, RL Meek, DD Raphael and PG Stein (eds) (Oxford 1978). 
communicate the intention to be bound, a community in which transactions take place, and the exchange of wealth. By assigning those investigations such paramount importance legal scholars engendered new insights into even the most closely analysed legal notion. The point they pressed with the greatest vehemence was that the price for achieving a theory-centred idea of law is the simplification of the legal discipline.

It may be added that once we turn away from a theory-centred idea of law we are in a position to rethink the time-honoured question of the relationship between ius commune and English common law. We may realise that the real problem is not whether Roman law had been the cement that united the two legal traditions - which poses some unanswerable questions ${ }^{117}$ - but shifting the focus from the study of norms to the ways they are applied in the real world, and examining new dimensions of their interrelation, for example to see how procedure evolved in accommodating new versions of legal reasoning. ${ }^{118}$ These sectors, so strictly dependent on general views about approaching the truth, require a philosophical key to understand their implications.

\subsubsection{The challenge of Law and Economics Among the alternatives to black-letter} law, it is worth briefly mentioning Law and Economics. The scholars associated with this movement also shared a distaste for a theory-centred idea of law, but unlike most others they had little interest in broadening the study of law: their purpose was to examine law under the perspective of economic theory only. From the 1970s to the 1980s this approach had an exponential growth, and it would be misleading not to consider that this was a further sign of the success story of Economics, started in the mid-19th century with the constitution of this field as an autonomous discipline, equipped with its own perspective made of specific methods and principles. Economics rose and expanded as an imperial science that colonised with its methods other fields; the first being Sociology and then Law, with an approach that its mentors, Richard Posner and Gary Becker, in some works published in the 1960s and 1970s called Economic Analysis of Law or Law and Economics. ${ }^{119}$ Recently this approach extended also to legal history, with undoubtedly original, though sometimes controversial,

117 See for example Jeffrey Hackney, 'More than a Trace of the Old Philosophy' in Peter Birks (ed), The Classification of Obligations (Oxford 1997) 123, at 130-135.

118 On this approach see David Ibbetson, 'Common Law and Ius Commune' (Selden Society 2001).

119 I am indebted in this section to Curzio Giannini, 'Economia e diritto: dall'imperialismo culturale al dialogo?' (1997) 13 Rivista di Storia Economica 363. The rise of Law and Economics is usually ascribed to the two following publications: Richard Posner, Economic Analysis of Law (1st edn, Boston 1973) and Gary Becker, 'Crime and Punishment: An Economic Approach' (1968) 76 Journal of Political Economy 169. The movement of Law and Economics, according to Richard Posner, must be placed within the broader area of legal realism: '[e]conomic analysis of law resembles legal realism primarily in claiming that legal rules and institutions have functional, social explanations and not just an internal, lawyer's logic; in this it is profoundly antiformalist', in R Posner, The Problems of Jurisprudence (London 1990) 441-442. A complete understanding of the rise of this field must however include Ronald Coase's seminal article 'The Nature of the Firm' (1937) 4/16 Economica 386; I am grateful to Giorgio Resta for bringing this article to my attention. 
results. ${ }^{120}$ Legal history, seen through the lenses of economic analysis, offers narratives in which the usual points of reference of legal thinking are missing. The jurist is puzzled, for law and economics look differently at the social world. We attempt to clarify their disagreement.

The special power of Law and Economics stems from a methodology based on a concise yet effective set of principles borrowed from the latter discipline. Firstly, the primary unit of analysis is the individual, and any explanation is based on the choices operated by the individual for the pursuit of self-interest (methodological individualism). Secondly, in making their choices, individuals are rational egoists who operate on the basis of perfect information (rational choice and economic efficiency). As the economist Curzio Giannini remarked, William of Ockham, who asserted that 'entities must not be multiplied beyond necessity' (entia non sunt multiplicanda praeter necessitatem), would have liked it. ${ }^{121}$

However, if the economist rejoices over the explicatory power of such parsimonious theory, the jurists would have some qualms. They begin from different premises. For example, let us turn to the basic question 'What is law?' For the economist law is an instrument to allocate resources in the most efficient way, and courts are the instruments that correct the failure of less-than-perfect markets, and replicate a perfect system of exchanges. Ideally, law should produce a perfect table of transactions untarnished by costs of transaction and uncertainty. The ultimate goal is to promote efficiency. On the other hand, economists in their analysis of law tend to replace justice with a view of efficiency and wealth maximisation, given that individuals tend to maximise wealth in the most efficient way following an essential feature of their psychology, with justice thus taking a secondary place. ${ }^{122}$ The jurist, on the other hand, cannot think about law in isolation from justice: she would deem it absurd to separate the two.

What is wrong, in the jurist's eyes, with Law and Economics? The answer is rooted in the intellectual history of this field. As we learn from its foremost mentor, Richard Posner, this movement finds its source in Jeremy Bentham. ${ }^{123}$ The movement found its beginning in an article published by Gary Becker in 1968 ('Crime and Punishment: An Economic Analysis'), which revived the thinking of the great British philosopher. This

120 See Jaakko Husa, 'Comparative and Economic Approaches to Law: A Tale of Wilful Misunderstanding?' (2012) 1 Comparative Legal History 105, reviewing S Deakin and K Pistor (eds), Legal Origin Theory (2012) also discussed in Alain Wijffels, 'Legal History \& Comparative Law', in S Besson, L Heckendorn and S Jubé, Comparing Comparative Law (Freiburg 2017) 187. In this fast-growing field, see also the essays collected in Daniel Klerman (ed), Economics of Legal History (Edward Elgar 2015).

121 Giannini, 'Economia e diritto', supra note 119, at 74.

122 Critical concerns with Law and Economics have been expressed by, among others, Martha Nussbaum, Amartya Sen and Robin Paul Malloy, see e.g. Martha Nussbaum, 'Flawed Foundations: The Philosophical Critique of (a Particular Type of) Economics' (1997) 64 University of Chicago Law Review 1197, and Giannini, 'Economia e diritto', supra note 119. For an overview of such criticisms see David M Driesen and Robin Paul Malloy, 'Critiques of Law and Economics' in F Parisi (ed), The Oxford Handbook of Law and Economics. Vol. 1: Methodology and Concepts (Oxford 2017).

123 Richard Posner, Frontiers of Legal Theory (Cambridge, Mass 2004) 31-61; Gary Becker, 'Crime and Punishment', supra note 119. 
article made a breakthrough, we learn from Posner, as 'it began to seem that perhaps no field of law could not be placed under the lens of economics with illuminating results'. This genesis clarifies the main features of this movement. In the first place the cult of facts, the appeal to empiricism, the use of non-legal categories and the interest for social-scientific research. Bentham was the intellectual model for the impatience for doctrinal abstractions, the war on obscurity; he had no time for abstractions and ridiculed words such as 'duty', 'obligation' and 'right' in a quip ('nonsense upon stilts'). Moreover, Bentham generalised the rational model of economic behaviour as a universal method of investigation, to use large-scale empirical research to accompany law reform, and the generalisation of the principle of utility maximisation. ${ }^{124}$

The extension of Law and Economics to legal history is part of the advancement of non-legal approaches in the social sciences. What worries the jurist most of all is the tendency to blur the boundary between jurisprudence and natural science. Economists are most interested in empirical facts: their leading idea is that law is a factual reality that must be analysed through methods of observation and empirical testing. Their confident statements such as: "[1]awyers, like the physical scientists, are engaged in the study of objective phenomena', uttered by Walter Wheeler Cook in 1924, ${ }^{125}$ suggest that natural sciences, equipped with their methods of observation and empirical testing, are the paradigm of a true science that must be emulated. Jurists, on the other hand, are suspicious of another set of methods to investigate the social world. They are suspicious of claims about the neutrality, objectivity and scientificity of economic analysis. It is indeed among the beliefs entertained by legal scholars that facts, in spite of the pragmatism that runs deeply among the most accepted assumptions of legal science, cannot be separated from values. ${ }^{126}$

Moreover, the jurist cannot think about law in separation from justice. Such a question has been raised by philosophers, for example by Martha Nussbaum who observed that wealth maximisation has no value if separate from justice. ${ }^{127}$ But jurists are also suspicious of an approach that presents a system without conflicts, or in which they masquerade as disagreements about facts. They insist that the observation of the social world shows conflicts over values, sometimes incommensurable, and it is the priority function of the law to find ways to settle disputes. Having two litigants who dispute their reasons in front of a judge is in the juristic mind the archetype of justice, and is thought to be preferable to a perfect system of transactions that prevents conflicts. Another criticism is that, paradoxically, one could see in Law and Economics another and newer incarnation of formalism. Economists, in a way somehow reminiscent of 19th-century formalism, introduce a set of principles (e.g. wealth maximisation,

124 Posner, 'Frontiers of Legal Theory', supra note 123, at 56, 61. On the persistence of this idea in the 'New Legal Realism', see Howard Erlanger et al., 'Is It Time for a New Legal Realism?' (2005) Wisconsin Law Review 335, 337.

125 Cited in Kantorowicz, 'Some Rationalism about Realism', supra note 85, 1247.

126 On this issue, usually discussed by evidence scholars, see, for example, Adrian Zuckermann, 'Law, Fact or Justice?' (1986) 66 Boston University Law Review 487; HL Ho, A Philosophy of Evidence Law: Justice in the Search for Truth (Oxford 2008); Kim Lane Scheppele, 'Facing Facts in Legal Interpretation' (1990) 30 Representations 42, and generally, John R Searle, The Construction of Social Reality (New York 1995).

127 Nussbaum, 'Flawed Foundations', supra note 123. 
efficiency, rational choice) which they then apply to the social world in a way that replaces the observation of real phenomena or even contradicts common experience. ${ }^{128}$

In conclusion, as we stand back from a theory-centred idea of law, we see that to study in isolation the conceptual apparatus to be found in legal texts- from its broad categories (say, property, contract, tort) down to the minute details - can be done at the price of leaving unexplored penumbral areas. Recent scholarship has been finding it more and more difficult to approach them without recognising that they arose from a cross-fertilisation of ideas. To understand them requires historical analysis as the proper investigation in the study of complexity.

\subsubsection{Against historicism}

3.2.3.1 The poverty of historicism Another assumption attacked by the antiformalist wave of 1930-60 was historicism. While Savigny, in the name of 'an organically progressive legal science' ( $\$ 2.3 .3 .1$ ), explained that change in law occurred in terms of a continuous and cumulative development, a new set of assumptions emphasised discontinuity, breaks and revolutions. To think of history as the teleological progression toward perfection, as Karl Popper wrote, was 'the poverty of historicism'.129 Legal scholars found it increasingly difficult to explain change by a theory that ordered events according to a linear conception of time. They found it easier to explain change by the idea that the past is separated from us by breaks or revolutions, and that knowledge does not grow from a piecemeal process of accumulation, but by clusters of basic ideas which replace each other. This argument, spearheaded by Thomas Kuhn and Robin Collingwood in their respective fields, ${ }^{130}$ had an impact on legal historical studies, suggesting a periodisation structured around successive revolutions, as for example Harold Berman did in his Law and Revolution (1983), building on the idea that 'the Western legal tradition was born out of a "revolution" and thereafter, during the course of many centuries, has been periodically interrupted and transformed by revolutions'. ${ }^{131}$

128 See for example Martha Nussbaum's remarks about the inefficacy of wealth maximisation in developing countries. See generally, after the 2007-2008 financial crisis, V Nourse and G Shaffer, 'Varieties of New Legal Realism: Can a New World Order Prompt a New Legal Theory?' (2009) 95 Cornell Law Review 61, linking law and economics to a 'new formalism'.

129 Karl Popper, The Poverty of Historicism (2nd edn, London 2002, written in the 1930s) 3: "I mean by "historicism" an approach to the social sciences which assumes that historical prediction is their principal aim, and which further assumes that this aim is attainable by discovering the "rhythms" or the "pattern", the "laws" or the "trends" that underlie the evolution of history'.

130 Thomas Kuhn, The Structure of Scientific Revolutions (Chicago 1962). On R Collingwood's 'theory of absolute presuppositions' see W Twining, 'R.G. Collingwood's Autobiography: One Reader's Response' (1998) 25 Journal of Law and Society 603, 615. The thesis of a discontinuity between 1780-1830 (Sattlezeit) has been claimed in R Koselleck, Futures Past (Cambridge, Mass 1985) and is a leading idea in Georges Gurvitch, L'idée de droit social (Paris 1932).

131 Harold Berman, Law and Revolution: The Formation of the Western Legal Tradition (Cambridge Mass 1983) 1; on which see Andreas Thier, 'Harold Berman's "Law and Revolution”: A Necessary Challenge for Legal History Research' (2013) 21 Zeitschrift des Max-PlanckInstituts für europäische Rechtsgeschichte 173. 
3.2.3.2 Against cumulative development Today, legal historians are increasingly hesitant to think about historical time in terms of an ever-growing line of ascent running up to the present day. This idea appears in narratives populated by 'seeds' that fructify in the present time, ancient 'roots' that extend to present-day ideas, precursors who anticipate our agendas, broad evolutions (e.g. 'from status to contract', 'from formalism to consensualism') or in the well-known line of juristic schools - glossators, commentators, French legal humanism, Dutch elegant school, natural law, usus modernus, German legal science - each of them handing the baton to the next school, in a direct line of ascent from the glossators up to us. Their unifying feature is the pervasive belief that knowledge grows in a piecemeal process of accumulation and progressive scientification that finds its apex in the present day. ${ }^{132}$

The idea of cumulative development is deeply intertwined with the 19th-century paradigm. As mentioned above $(\S 2.3 .2 .2)$, legal scholars were inclined to view law as a pure and de-contextualised entity. They drew their normative material from the Corpus Juris Civilis, but unmindful of its historical dimension. They saw it as a body of laws in a perfected state, and the distinctive claim they went on to offer was to view it as an immense storehouse of solutions. In their mind it was a universal grammar which, as a sort of a Wohltemperierte Klavier of juristic science, dictated principles to apply in any time and place.

There are three features in the vision of cumulative development of the law that deserve to be noted. The first is that such law evolved in a vacuum, untarnished by external influences - its Isolierung, as Fritz Schulz famously wrote, being one of its core principles. ${ }^{133}$ But current scholarship faces growing difficulties in perceiving a clear line that separates an internal from an external side of the law's history (§ 2.3.2.2). Secondly, the idea of cumulative development, by demonstrating through a linear evolution how current law has taken the form it had in the present time, implies a narrative shaped around the argument of inevitability, shown for example in statements such as 'we had a ius commune yesterday; we will have a ius commune tomorrow'. At the same time, such linear evolution cannot be drawn without a sharply judgemental narrative. Its main preoccupation is in fact to select what is 'in' and what

132 A sweeping criticism in Douglas Osler 'The Myth of European Legal History' Rechtshistorisches Journal 16 (1997) 393. A similar concern focuses on the canon of selected 'classics' (Plato to John Stuart Mill) established in the early 19th century, on which see Siep Stuurman, 'The Canon of the History of Political Thought: Its Critique and a Proposed Alternative' (2000) 2 Political Theory 147. Vocal on this score is Robert Blakey's, History of Political Literature from the Earliest Times (1855) I, 414: 'We personify time by calling it the spirit of progress; which moves onward with a steady and unfaltering step. There is no hesitation, no falling back. It is the True; it is the Just; it is the Right; it is the one and indivisible; the same in all the countries and climes; the same now it will ever be ... The history of society is, then, the history of progress.' For a general orientation see P Burke, 'Western Historical Thinking in Global Perspective - 10 Theses' in Jörn Rüsen, (ed), Western Historical Thinking: An Intercultural Debate, supra note 6, at 17-19.

133 Fritz Schulz, Principles of Roman Law (Oxford 1936) 19-39. For a critical reconsideration see Kaius Tuori, Ancient Roman Lawyers and Modern Legal Ideals: Studies on the Impact of Contemporary Concerns in the Interpretation of Ancient Roman Legal History (Frankfurt 2007) 71, and Yan Thomas, Mommsen et l'Isolierung du droit (Rome, l'Allemagne, et l'État) (Paris 1984). 
is 'out' among the forces that contributed to or hampered its evolution. The opposition between humanism and bartolism is a case in point. But current scholarship, as we have seen $(\$ 2.3 .1 .3)$, is increasingly hesitant to perceive such a deep divide. The third feature is the inclination of cumulative development towards a legal history overtly engaged with present concerns, which requires separate attention in the following section.

\subsubsection{Understanding the present legal world To explain legal change in terms of} cumulative development may seem naive or simplistic, but it nevertheless has a considerable importance for offering a view of legal history openly engaged with contemporary concerns - or in other words, for making legal history useful. ${ }^{134}$ This is not a little thing, for this being 'useful' justifies and even aggrandises legal history's position in the legal curriculum.

It is precisely the aim of recapturing the former greatness of legal history that is one of the main implications of the call put forward by Reinhard Zimmermann for reviving Savigny's legacy. His argument (put in the simplest terms) is that Savigny's project of a union of legal history and legal science ('historical legal science', § 2.3.3.1) was the premise for paving the way to the German codification of private law (BGB). And today, that union of law and history, successfully claimed by Savigny in his own time, could be the foundation for a common law for Europe. The normative material is already at hand, in the Roman law that has evolved, as Savigny claimed, 'in indissoluble communion with the past', 135 from Justinian to the present day. This ambitious design replicates Savigny's wish of taking back legal history to the former central position in legal science. ${ }^{136}$

This project stirred a wide discussion (which is beyond this chapter to consider) and an interesting question directly relevant to our discussion. The compelling argument put forward by Reinhardt Zimmermann leads to a version of legal history that is directly engaged with the present time and is therefore 'useful'. This argument had a powerful effect that produced both fervent admiration and staunch disagreement. When some legal scholars disagreed, they did it in the name of the integrity of their discipline, which must be free of instrumental objectives. The distinctive claim they went on to advance was to stress that legal history must be impervious to external aims, in order to be true to its nature. Their alternative to Zimmermann's applicative legal history was a 'contemplative' legal history; some scholars also asserted that their craft must be 'useless'.137 If so, a question arises naturally: is the province of legal historiography truly divided between two contrasting approaches, applicative and contemplative legal

134 Dirk Heirbaut, 'A Tale of Two Legal Histories', in Dag Michalsen (ed), Reading Past Legal Texts, supra note 62, 91.

135 Friedrich Karl von Savigny, 'Über den Zweck dieser Zeitschrift', supra note 64, at 2-3. See also Savigny's idea that our law develops 'in unauflösischer Gemeinschaft mit der ganzen Vergangenheit'.

136 Reinhard Zimmermann, 'Savigny's Legacy: Legal History, Comparative Law, and the Emergence of a European Legal Science' (1996) 112 LQR 576.

137 See, for example, Pietro Costa, 'A che cosa serve la storia del diritto? Un sommesso elogio dell'inutilità' in O Roselli (ed), La dimensione sociale del fenomeno giuridico (Napoli 2007) 23. 
history, or, to put it bluntly, borrowing Dirk Heirbaut's sharp expression, between 'Dienstmagd oder Nichtsnutz' ('servant or a good for nothing')? Or is there a third option that transcends both? ${ }^{138}$

The question is piercing. During the past decades legal historians have seen the rise of an unprecedented methodological concern in historical research, and they are increasingly aware that their work must be methodologically accomplished. But at the same time they are hesitant to accept that there is a price to pay for such awareness: being true to their object means to seal it off from the present legal world. Particularly clear on this score is Martti Koskenniemi. He argues that a full-scale contextualism fails to provide an appropriate framework in which there is present a tension between the legal past and our time, nor can it appropriately explain changes in law. For example, writing on the 16th-century jurist and theologian Francisco de Vitoria, he notes that:

[The] attention of a critical historian of international law cannot be limited to the careful reconstruction of the contexts in which Vitoria worked but must also examine how those contexts were formed and to what extent they have persisted to make international law what it has become today. ... This means directing attention to special context-breaking moments, practices that transform what was earlier taken for granted, as well as the accompanying hierarchies. ${ }^{139}$

The tension involved in understanding the present legal world is perhaps one of the constitutive traits of recent legal historiography. We learn for example from John Dawson's 'Introduction' to his Oracles of the Law, that '[t]his study will examine the nature and extent of the contribution that case law has made to the legal systems of England, Rome, France, and Germany. The emphasis will be historical, but the object will be to show the lasting effects of historical experience on modern usage and attitudes'. ${ }^{140}$ Gino Gorla in his study of contracts (1954) presents the historicalcomparative approach 'as a method for a more correct understanding of our positive law, as a problem that is immediate, practical, contemporary'. He also declares that this method, because of the historical-comparative element, is distinct from comparative law, which is solely addressed to gathering information from other legal systems (Preface, p. v). Turning to more recent works, David Ibbetson's Historical Introduction to the Law of Obligations (1999) argues that '[i]f we are to make sense of today's law we have to understand its history, and it is only when we can make sense of it that we can confidently begin to reform'. ${ }^{141}$ In his Philosophical Origins of Modern Contract

138 Dirk Heirbaut, 'Comparative Law and Zimmermann's New Ius Commune: A Life Line or a Death Sentence for Legal History? Some Reflections on the Use of Legal History for Comparative Law and Vice Versa' (2005) 11 Fundamina 136, 146.

139 Martti Koskenniemi 'Vitoria and Us' (2014) 22 Rechtsgeschichte-Legal History 119, $134-135$.

140 John Dawson, The Oracles of the Law, supra note 31, xi, and in the Foreword (p. v) Dean Allan F Smith observed: 'Probably the ideal goal of historical and comparative writing is to create a document which functions both to provide new insights into the past simply for the sake of understanding and to provide perspective which casts light on current issues and illuminates potential future courses of action'.

141 David Ibbetson, An Historical Introduction to the Law of Obligations (Oxford 1999), vi. 
Doctrine (1991) James Gordley advocates an historical analysis of its philosophical basis in order to clarify the incoherence of the present day's contract law. ${ }^{142}$

The above-mentioned statements are just examples and cannot be generalised, but they nevertheless show how pervasive is the belief that there is no contradiction between historical research and the attempt to understand the present legal world. In fact, they suggest that legal history, although most of the time pursued in dusty archives amid old books, aspires to be more than an exercise in antiquarianism, and to actively engage with present-day law. The real problem is to clarify the nature of its contribution, which takes us back to the question mentioned above: is there a third option beyond applicative and contemplative legal history?

3.2.3.4 Deactivating the grip of tradition Some antiformalist writings of the period 1930-60 offer an alternative that transcends the above-mentioned dilemma. ${ }^{143}$ They suggest that historical research, as methodologically accomplished as it could possibly be, does not necessarily seal off the past. Rather, it contributes to the understanding of the present world, and in this sense is 'useful'. Such a vision comes from the awareness that civilian legal thinking is deeply embedded in a legal tradition. One of its main features is to exert a constraint on the jurists who work within it. They cannot escape from it and tend to believe that their inherited intellectual commitments are the only guidance they have to think about the law. This constraining power is particularly considerable for the civilian. This tradition is more than the presence of the past in the law (Patrick Glenn: 'pastness') ${ }^{144}$ as the civilian works with a past that has a normative content. In this tradition law developed as a living body, whose authority was located in a historical text, Justinian's compilation, handed down (traditum) from generation to generation, and its authority was combined with that of the community of interpreters who elaborated it dogmatically; they were bound to the text by a fideistic commitment. As Paul Koschaker wrote, interpreters cannot study dogmatically a text in which they do not believe, as they could undermine its authority. ${ }^{145}$ The codifications upgraded Roman law to a sort of natural law that dictated a grammar of universal value, accompanied by an abstract style of thinking which argued that a pure and de-contextualised legal science was the only way of thinking about law. A tradition can be worrisome: 'Tradition ist Schlämperei', according to Gustav Mahler's formula.

142 James Gordley, The Philosophical Origins of Modern Contract Doctrine (Oxford 1991) 9; on the comparative character of this work see Charles Donahue, 'Comparative Legal History in North America' (1997) 65 Tijdschrift voor Rechtsgeschiedenis 1, 16.

143 For the Italian jurist the reference is to a range of writings, most notably Riccardo Orestano, Introduzione allo studio storico del diritto romano (Turin 1953), which includes also the revival of the historical dimension of Legal Humanism, specifically Domenico Maffei, Gli inizi dell'umanesimo giuridico (Milan 1950), developed in Anglophone scholarship by Donald Kelley. In the broader field of the history of political thought, see Quentin Skinner, Visions of Politics. Vol. 1 Regarding Method (Cambridge 2002) 6-7.

144 Glenn, Legal Traditions of the World, supra note 98, at 5-6.

145 According to Paul Koschaker, 'niemand kann ein Recht dogmatisch untersuchen, an dessen Autorität er nicht glaubt' in Paul Koschaker, Europa und das römische Recht (MunichBerlin 1966) 338, discussed in Giaro, 'Diritto Romano Attuale', supra note 28, 79. 
History can deactivate this grip. While the adherents to a tradition believe in its authority, historians are free from this constraint. For them, as we learn from Tomasz Giaro, knowledge does not imply acceptance. ${ }^{146}$ Thus, they are not bound to believe and can be sceptical about any normative value located in the past: they are just observers. Given this background, historical research can deactivate the grip of tradition. Its role becomes 'useful' when we look at the concepts and doctrines to be found in legal texts. From the basic ideas (say, property, contract, tort) down to the minute details we realise how much current ways of thinking about them reflect influential accounts inherited from the 19th century, as most of what we know of law, both substantive and procedure, was written at that time. History brings concepts and ideas back to the place they have in historical time and examines them divested of their normative value, as historical facts. ${ }^{147}$ It is in the essence of such pervasive concern with the historical dimension of law that recognition is found of its special power in exorcising the grip of tradition and in offering a view of the law unencumbered by inherited constraints.

\subsubsection{History before historicism Another route to escape from historicism is} offered by reverting to forgotten ideas of historiography, and, most notably, to the view of history conceived as a reservoir of examples. ${ }^{148}$ To understand this notion we need to go back to a simple statement concisely expressed in JH Zedler's Lexicon (1735): '[f]or that which we cannot ourselves experience, we have to follow the experience of others'. ${ }^{149}$ This suggests that to act in practical life requires experience and only the individual who possesses it is deemed to be fit for action. If so, examples are premises for action, and they are at the heart of history, as it is the essence of this discipline to teach past achievements in order to avoid failures ('historia magistra vitae'). Its usefulness (utilitas historiarum) was in fact one of its recurrently cited features. Nineteenth-century historicism made tabula rasa of this idea. It ridiculed the view that history could be a reservoir of examples: it was more ambitious. It transcended mere facts to be upgraded to an intellectual construction whose highest achievement was to reach an overarching unity which received meaning from such coherence. Savigny declared that history was "not any longer a collection of examples but the only way to

146 Giaro, 'Diritto Romano Attuale', supra note 28, 79.

147 See for example the third thesis of the Trento Manifesto of comparative law (1987): 'Comparison turns its attention to various phenomena of legal life operating in the past or the present, considers legal prepositions as historical facts including those formulated by legislators, judges and scholars, and so verifies what genuinely occurred. In this sense, comparative law is an historical science', cited in E Grande 'Development of Comparative Law in Italy' in Reimann and Zimmermann, Oxford Handbook of Comparative Law, supra note 3, 107 at 118.

148 On which see Antony Grafton, What was History? The Art of History in Early-Modern Europe (Cambridge 2007); and GH Nadel, 'Philosophy of History Before Historicism' (1964) 3 History and Theory 291.

149 JH Zedler, Universal-Lexikon (Halle and Leipzig 1735) Vol 13, 281, cited in R Koselleck, 'Historia Magistra Vitae: The Dissolution of the Topos into the Perspective of a Modernized Historical Process' in Futures Past: On the Semantics of Historical Time (Cambridge Mass 1985) 27. 
know our condition'.150 This intellectual enterprise was named Geschichte (in the singular) in order to highlight its essential unity; Humboldt wrote of 'events as part of the whole' and Kant of the 'natural unity of history'. ${ }^{151}$ Events were fused in an overarching plan which united a multitude of singular events into one. As mentioned before, this unity was also achieved by ordering the material into external/internal history, to dominate it at a glance.

Today, the idea of history as a reservoir of examples is back in a number of contexts. It has been revived by scholars who believe that the writing of history should overcome a Eurocentric perspective. As we learn from the German historian Jörn Rüsen, such a reservoir collects experiences, and they are relevant solely for being part of experience, independently from a given ethnocentric perspective. Such efforts arise from the unrest at reviving other dimensions of temporality, for example conceptualising time in terms of individual or collective memory, or looking back to forgotten ideas of temporality, such as to the Greek kairos, understood as 'right time' as opposite to the more familiar idea of a uniform and computable time (chronos). ${ }^{152}$ More broadly, these efforts are part of a general rethinking of the basic periodisation of the historical past, conventionally shaped around the tripartition of Antiquity, Middle-Ages and Modernity, which seems hardly justified in a non-Eurocentric history. ${ }^{153}$

At a broader level, such growing attention to alternative ideas of history goes hand in hand with a growing curiosity over other styles of thinking about the law. Reasoning by examples, paradigms and cases are a broad range of styles of thinking about the law which belong to intellectual traditions side-tracked by 19th-century scholarship and which today are revived as they bring to light overlooked dimensions in familiar notions. For instance, the word 'example' belongs to the vocabulary of judicial procedure, in which exemplum is another word for precedent (Justinian's Codex 7.45.13: 'non exemplis sed legibus iudicandum est' ['we should judge by laws, not precedents']) and whose explicatory power rests in reasoning by analogy. ${ }^{154}$ Ancient rhetoric conceptualised exampla under the broad heading of testimony (external evidence) and therefore as bits of knowledge derived from someone else's experience; they came, as it were, from outside, and were contrasted with the individual rational

150 Savigny 'Über den Zweck dieser Zeitschrift', supra note 64, at 4: 'Die Geschichte ist dann nicht mehr blos Beyspielsammlung, sondern der einzige Weg zur wahren Erkenntinis unsers eigenen Zustandes'.

151 R Koselleck, 'Historia Magistra Vitae', supra note 149, 35.

152 Jörn Rüsen, Western Historical Thinking: An Intercultural Debate, supra note 6, 4-5; P Sipiora, JS Baumlin (eds) Rhetoric and Kairos: Essays in History, Theory, and Praxis (New York 2002).

153 See the alternative periodisation offered in Richard Ingersoll and Spiro Kostof, World Architecture: A Cross-Cultural History (Oxford 2012).

154 'Example', according to Quintilian, refers to 'matters that were previously decided for similar reasons, which are more accurately described as examples' cited in J Dawson, The Oracles of the Law, supra note 31, at 120 n 3. Johann Kahl (Calvinus), Lexicon Juridicum (Cologny 1612), col. 1024, s.v. 'exemplum': 'Exemplum accipitur ... pro specie argumentationis: cum probatur aliquid ex simili facto, cum citatione auctoris' ("The word "example" indicates a kind of argument by which something is supported by stating a similar fact and citing the author'). See also C Ando, 'Exemplum, Analogy, and Precedent in Roman Law' in M Lowrie and S Lüdemann (eds), Exemplarity and Singularity (London 2015) 111. 
elaboration (internal evidence). The example/precedent offers the ground to decisionmaking but without being binding: it is a persuasive authority, which offers an open possibility without leading to a necessary conclusion.

3.2.3.6 The comparative element After having described the rise of comparative legal history in terms of a new set of assumptions that redirected legal-historical research from the mid-20th century, it is time to turn to the word that summarises this intellectual enterprise. What does this word, 'comparative', mean placed next to the more familiar term 'legal history'? The legal historian faced with this question would naturally turn to the academic field of comparative law, but soon realise that an explanation has never ranked highly in this field's research agenda. According to the comparatist John Wigmore, this is a 'convenient but loose word', and more recently Nils Jansen observed that ' $[\mathrm{t}]$ he question of what comparison really means has until recently never been seriously asked, let alone answered'. ${ }^{155}$

A legal historian could perhaps help with a clarification. The study of confused or ambiguous terms belongs to this discipline. The reason is that the legal historian is particularly sensitive to the notion that words indicate ideas, and the rise of a new word - in this case, 'comparative' - in the vocabulary of a scholarly community is the first and clearest sign of a new constellation of ideas and concepts that acquires currency within it. Legal scholars use that new vocabulary to discuss those ideas, and project upon it their new range of beliefs and expectations. This is a language game in which the historian is particularly keen about perceiving and clarifying. What is then this new comparative idea? If we turn to what comparatists usually say about the evolution of their field, we can hardly fail to notice that one widely shared view is that this field underwent through two major phases from its rise in the late 19th century, each of them led by its own comparative idea.

The first phase - 'la Belle Époque du droit comparé', according to Bénédicte Fauvarque-Cosson ${ }^{156}$ - sees the consolidation in the early 20th century of comparative law as a new and autonomous discipline. Comparatists usually agree that this discipline started from the Congress of Paris of 1900. To understand such an innovative impetus we must consider the grandiose message furthered by the Exposition Universelle within which this Congress was set out. This event was intended to showcase a deeply felt atmosphere of optimism for a new century that opened with the view of a civilisation that expanded on a world-wide scale. A similar anxiety pervaded comparative law. As we learn from its masterminds, Edouard Lambert and Raymond Saleilles, this new legal discipline received life from the ideal of a 'droit commun de l'humanité civilisée' that unified all existent positive law in a universal law, which this discipline was meant to fulfil. Comparatists set their best efforts in grasping this burgeoning institutional world. They saw it as a wide constellation of unified and autonomous nation-states to

155 John Wigmore is cited in Walther Hug, 'The History of Comparative Law' (1932) 45 Harvard Law Review 1027, 1027; Nils Jansen is quoted from his chapter 'Comparative Law and Comparative Knowledge' in Reimann and Zimmermann (eds), Oxford Handbook of Comparative Law, supra note 3, 307.

156 Bénédicte Fauvarque-Cosson, in Reimann and Zimermann (eds), Oxford Handbook of Comparative Law, supra note 3, 42-47. 
understand in terms of a description of their characteristics. Accordingly they went on categorising them under legal families, guided by the belief that the legal world could be mapped through a taxonomic table. Such a pursuit was entrenched in a network of assumptions arising from the 19th-century paradigm, described in Section 2 of this chapter as an exclusive concern with black-letter law, the belief in a pure definition of law, and the idea that law evolved by cumulative development. It was perhaps this last point, the absence of history, that was the most evident feature shown by this first phase: the taxonomy it implied dealt with an essentially static subject matter.

The second phase belongs to the post-World War II period. ${ }^{157}$ Comparatists felt disenchanted with the 19th-century paradigm, as legal historians did in their own field, and particularly with the taxonomic project, which had lost its appeal. Missing their major unifying feature, they opened multiple directions of study, as Otto Kahn-Freund put it, enjoying the 'gift of freedom' in devising their object and method; accordingly, they moved towards highly diversified patterns of research. ${ }^{158}$ Today this field offers a view of the fragmentation of paths and methods: no fewer than 18 methodological approaches are recorded in Reimann and Zimmermann's Oxford Handbook of Comparative Law. Such a lack of a common intellectual ground is lamented by Nils Jansen as a 'methodological disease' that prevents coherence and turns this field, as Mathias Reimann puts it, into 'a potpourri of disparate elements that coexist side-by-side but rarely relate to any overarching theme'. ${ }^{159}$ However, there are two approaches in this list that capture the attention of the scholar engaged with legal history: one arises from the idea of law as tradition developed by Patrick Glenn, the kernel of which is a time-embedded idea of law; ${ }^{160}$ the other is the turn to historical research. They are both engaged with the understanding that innovation in law comes not only from new and unprecedented ideas but also from reconsidering ancient forms of law and legal thinking. Part of this interest for an historical dimension is the concern for another and older meaning of comparison.

My argument is that they revive an older meaning of comparison. A sometimes overlooked fact, which the legal historian would not fail to highlight, is that 'comparative' is an ancient word. It had a place in the vocabulary of medieval and early-modern law, and was used in a world in which jurists spoke of comparatio (noun) and comparative (adverb) to indicate aspects of their multinormative environment. They discussed the interrelation between plural legal orders in specific works focused on

157 M Reimann, 'Progress and Failure of Comparative Law in the Second Half of the 20th Century' (2002) 50 Am J Comp L 671, 680.

158 Otto Kahn-Freund, 'Comparative law as an Academic Subject' (1966) 82 LQR 40, 41, cited in Reimann, ibid, 688.

159 This is the theme of Part II ('Approaches to Comparative Law', pp. 305-868) of Reimann and Zimmermann's Oxford Handbook of Comparative Law, supra note 3. The first citation is from N Jansen, 'Comparative Law and Comparative Knowledge', supra note 155, 308; the second from M Reimann, 'Progress and Failure', supra note 157, 686.

160 HP Glenn views tradition as a network of information or communication of information over time in his Legal Traditions of the World, supra note 98, at 21-22 and 13. On the debate provoked by this book, see the essays collected in NH Foster, 'A Fresh Start for Comparative Legal Studies? A Collective Review of Patrick Glenn's Legal Traditions of the World' (2006) 1 Journal of Comparative Law 100. 


\section{4}

their reciprocal comparison (treatises de comparatione), in which they wrote that the plurality of normative orders required a 'comparative' knowledge and the judge in settling a dispute knew laws 'comparatively'. ${ }^{161}$

By doing so those jurists were describing an aspect of their legal reasoning. They sometimes wrote of arguing 'comparatively' (comparative loqui) by reasoning about the relations between things or ideas, and contrasted this with arguing 'absolutely' or 'exclusively', by which they meant to separate the given subject matter from its context. This idea is further clarified when we turn to ordinary language. The massive Lexicon compiled by Egidio Forcellini (1688-1768) tells us that strictly speaking ('stricto sensu') comparatio is about thinking in relation to another person or thing ('quod comparatur sine altero non intelligitur'). Its kernel, which explains this intellectual operation, is reasoning by analogy. Comparatio is in fact the Latin word (together with proportio) that Cicero, in his translation of Plato's Timaeus, suggested to

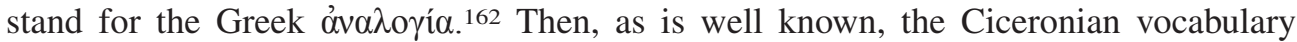
came to be the unquestioned model of learned language until the 16th century. This brief detour tells us that at the heart of this comparative idea is the familiar pattern of reasoning by analogy. As the legal theorist Lloyd Weinreb stresses, analogy, while not exclusive of legal thinking, is a style of reasoning which is alternative to patterns of thinking stemming from systematic reasoning: reasoning by analogy is the essence of a case-law system. To think like a lawyer in such a legal world means in most cases to argue from relational ideas ('comparative ad alterum': comparatively to something else).

It is true that medieval and early-modern legal texts offer a view of a world that we can hardly understand because of an incommensurable intellectual gulf which sets us apart. But that lexicon offers a link that has been transmitted to the present time and is currently used, as any contemporary private law manual would show. It should be unsurprising that today's jurists use the word 'comparative', which had a place in there for some centuries to indicate a normative environment conceptualised as multinormative. A medieval jurist would more readily understand the present-day use of the word comparative than, say, the word marriage. ${ }^{163}$

161 One of such works was Giovanni Paolo Lancellottti's De comparatione iuris pontificii et caesarei (1573), examined in A Giuliani, 'Jurisdictional Complexity in the Ecclesiastical State: A Discussion on the Diversity of Laws in Legal Education and Legal Practice', in S Donlan and D Heirbaut (eds), The Laws' Many Bodies: Studies in Legal Hybridity and Jurisdictional Complexity, c1600-1900 (Berlin 2015) 35-56.

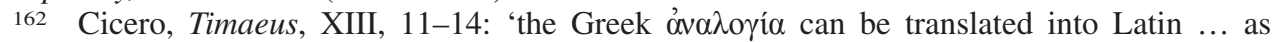

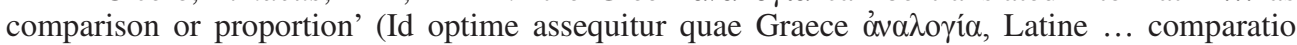
proportiove dici potest), cited in Forcellini's Lexicon s.v. 'comparatio' under the heading 'comparatio stricto sensu'. On this see generally F Schironi, 'óva ratio: Loanwords, Calques and Reinterpretations of a Greek Technical Word' in L Basset, F Biville, B Colombat, P Swiggers and A Wouters (eds), Bilinguisme et terminologie grammaticale gréco-latine, 'Orbis - Supplementa' 27 (Leuven et al. 2007) 321-338.

163 On the illusion of semantic continuity, in spite of the unchanged verbal shell, in reference to the term 'matrimonium' see Marta Madero, 'La nature du droit au corps dans le mariage selon la casuistique des XIIe et XIIIe siècles' (2010) 6 Annales Histoire, Sciences Sociales 1323; on multinormativity, see Thomas Duve, 'European Legal History - Concepts, Methods, Challenges', supra note 9, at 55-60. 
In this understanding legal scholars are inclined towards the ancient meaning of comparison. They bring to light a forgotten meaning which becomes particularly evident when we realise that at the heart of legal research is the recognition of a multinormative environment. One of the features of their research is to redirect their focus to that direction; for example, Seán Patrick Donlan focuses on the 'historical study of relational normativity' and Michele Graziadei on the 'law's interaction with other legal orders', while Charles Donahue indicates that among the tasks of comparison is 'the careful examination of top-level ideas, middle-level legal discourse, and actual practice and development'. ${ }^{164}$ Important streams of research are moved by this idea. By doing so, they simply come to terms with issues emerging from the current legal world. As we argued above $(\S 1)$, the writing of legal history begins from an image of law. And the latter rises from a legal world whose protagonist is the judge, which accordingly guides historical research in choosing its object of study and the appropriate approaches. Guided by this image, the historian imitates the judge, who reasons comparatively.

It is time to look more in detail at the judge and the historian. This well-known image brings to light a connection between the legal world and the ways to write its history. When this image first appeared in legal scholarship in the 1930s, jurists learnt an important lesson from historians. Those jurists realised that the judge dealing with the question of fact ('what happened?') acted like an historian, and that was indeed the decision-making's key phase; they accordingly reconsidered the nature of the decision process. In that instance, historians clarified how judges work. ${ }^{165}$

Let us go back to this image, but this time looking at judges. When we look at the following phase of the decision-process, the question of law ('which is the law to be applied to the disputed facts?'), we realise that judges work in a vastly changed operative milieu. We register the fragmentation of state sovereignty and the concurrent erosion of the state's function as producer of law. Jurisdiction, the essential function of state sovereignty, extends beyond the state, and the judiciary - the direct expression of its territorial sovereignty - is progressively detached from its state-bound framework. ${ }^{166}$ Looking at the normative milieu, we see that judges are immersed in a plurality of legal orders which reflect the ongoing multiplication of normative sources and thus of jurisdictions. Their choice about competing sources is accompanied by a persistent concern with the degree of their authority. They work, as Rosalyn Higgins suggested, in a 'Babel of judicial voices', persistently challenged by the question 'Which of the many

164 Seán Patrick Donlan, 'Comparative? Legal? History? Crossing Boundaries' in this volume; Michele Graziadei, 'Comparative Law as the Study of Transplants and Receptions' in Reimann and Zimmermann (eds), Oxford Handbook of Comparative Law, supra note 3, at 471-472; Charles Donahue, 'Comparative Law Before the Code Napoléon', in Reimann and Zimmermann (eds), Oxford Handbook of Comparative Law, supra note 3, at 22.

165 P Calamandrei, 'Il giudice e lo storico' (1939) 17 Rivista di diritto e procedura civile 105; M Taruffo, 'Il giudice e lo storico. Considerazioni metodologiche' (1967) 22 Rivista di diritto processuale 438. In the broader field of intellectual history, see Carlo Ginzburg, 'Checking the Evidence: The Judge and the Historian' (1991) 18 Critical Inquiry 79.

166 S Cassese, Il diritto globale. Giustizia e democrazia oltre lo stato (Turin 2009) 137; N Picardi, La giurisdizione (Milan 2007) 174-183. 
norms now developed are applicable'? ${ }^{167}$ For the purposes of our argument, we readily acknowledge that in this milieu, the judges' knowledge is essentially, using an old word, comparative, and that their laws must be known comparatively. It should come as no surprise that legal historians update their vocabulary in accordance to what happens in the real world.

\section{CONCLUSION}

So, what is comparative legal history? If the answer is sought from a legal historian, as in the present chapter, this would arise from analysing the process that gave rise to this field of enquiry, leaving aside, as not directly congruent with this endeavour, the search for a definition. To proceed, the first question to settle regards how the writing of legal history changes in time, and one of the main suggestions offered by this chapter is to view this discipline as an intellectual tradition strictly dependent on an image of law and a set of assumptions about its nature - what is law, by whom is it created and how. This premise shows that a set of path-breaking insights gave life to a raft of works self-styled as comparative legal history published in the period 1930-60. These works were part of a broader argument against 19th-century formalism which attacked three of its basic assumptions: the exclusive concern with black-letter law (textualism); the wilful separation of law from its context (purity); and the idea that knowledge grows in terms of a linear and cumulative development (historicism). The importance of going back to that juncture lies in the fact that those critical utterances, expressed then by a handful of legal scholars, in the course of time have been generalised into broad assertions - e.g. to place law in context, to think outside the doctrinal box, the distaste for abstract theorising. It is true that they fuelled original legal-historical research and today are shared as an obvious truth, but it is precisely because of their broadness that we need to place them into the intellectual context from which they originated, in order to understand what at that time they rejected and what was placed in their stead.

The idea of legal historiography as a tradition is central for two reasons. First, it alludes to the coherence of the writing of legal history given by its being intertwined with an image of law and a set of assumptions that guide its writing. But it also shows that it may modify or even metamorphosise into another tradition when its premise - a set of assumptions about law - changes. It suggests a view of legal historiography in the broader field of law, deeply intertwined with claims arising from the broad intellectual and institutional context.

Secondly, it sounds an alarm about the constraining power exerted by the intellectual heritage. When we look closely at the law, from the broadest ideas - say, property, contract, tort - down to the minute details, we realise how much our understanding reflects influential accounts inherited from the 19th century, given that most of what we know of private law and procedure was written at that time. But at the same time this restraint is felt to be unendurable by current scholarship. As Thomas Duve writes, 'we need to de-Germanize research traditions, freeing ourselves

167 Rosalyn Higgins, 'A Babel of Judicial Voices? Ruminations from the Bench' (2006) 55 International and Comparative Law Quarterly 791. 
in some aspects from constraints imposed by the tradition, heavily influenced by German authors'. ${ }^{168}$ One of the main ideas offered by this chapter is that history can deactivate the grip of traditions. This chapter, in fact, can be read as an attempt to test this power precisely in the field of legal history. Its purpose in going back in Section 2 to Gottfried W. Leibniz, Jacques Berriat-Saint-Prix, Gustave Hugo, Frederick Savigny and other masterminds of legal historiography, is to show that some of those broad conceptions which have been guiding the making of legal history until recently - for example, the contrast between bartolism and humanism, the idea of cumulative development, the distinction between internal and external history - were the contributions of leading thinkers to a legal world that is vastly distant from ours. We need to understand the past to be aware of their constraining power and start to rethink the legal field in a spirit of inquiry free from the constraints of inherited intellectual commitments. This is in fact one of the main contributions that legal historiography can offer to the understanding of the present legal world.

If this analysis is correct, the rise of comparative legal history is more than a turn towards a cosmopolitan approach. One may remember the prophecy uttered by Frederic Maitland in 1901 that one day the pendulum of scholarship would be swinging towards cosmopolitanism. ${ }^{169}$ Of course this shift occurred, but it would be misleading to take it as the only feature of this field of inquiry, for this is more than a legal history with cosmopolitan flair that studies the differences and similarities between geographically distant legal systems. This chapter argues that the rise of comparative legal history signals a deep change in the understanding of law and in the ways to write its history.

168 Thomas Duve, 'European Legal History', supra note 9, at 60.

169 F Maitland, English Law and the Renaissance (The Rede lecture for 1901, Cambridge 1901) 8 . 